\title{
Description of 11 new Astiella (Spermacoceae, Rubiaceae) species endemic to Madagascar
}

\author{
Inge GROENINCKX ${ }^{1}$, Steven JANSSENS ${ }^{2}$, Erik SMETS $^{3} \&$ Brecht VERSTRAETE $^{4, *}$ \\ ${ }^{1}$ Plant Conservation and Population Biology, KU Leuven, Kasteelpark Arenberg 31, \\ P.O. Box 2435, 3001 Leuven, Belgium. \\ ${ }^{2}$ Botanic Garden Meise, Nieuwelaan 38, 1860 Meise, Belgium. \\ ${ }^{3}$ Naturalis Biodiversity Center, P.O. Box 9517, 2300 RA Leiden, The Netherlands. \\ ${ }^{4}$ Natural History Museum of Denmark, University of Copenhagen, Sølvgade 83S, \\ 1307 Copenhagen, Denmark. \\ ${ }^{1}$ Email: inge.groeninckx@kuleuven.be \\ ${ }^{2}$ Email: steven.janssens@botanicgardenmeise.be \\ ${ }^{3}$ Email: erik.smets@naturalis.nl \\ ${ }^{*}$ Corresponding author: brecht.verstraete@snm.ku.dk
}

\begin{abstract}
Astiella is an herbaceous genus endemic to Madagascar, originally described with a single species A. delicatula Jovet. Molecular and morphological evidence place it in the tribe Spermacoceae s. lat. of Rubiaceae. During herbarium studies and fieldwork in Madagascar, 11 new Astiella species were identified and these are described here: A. antongilensis Groeninckx sp. nov., A. antsalovansis Groeninckx sp. nov., A. confusa Groeninckx sp. nov., A. deblockiae Groeninckx sp. nov., A. desseinii Groeninckx sp. nov., A. homolleae Groeninckx sp. nov., A. latifolia Groeninckx sp. nov., A. longifimbria Groeninckx sp. nov., A. perrieri Groeninckx sp. nov., A. pulla Groeninckx sp. nov., and A. tsaratanensis Groeninckx sp. nov. The genus Astiella now holds 12 species in total that are all endemic to Madagascar.
\end{abstract}

Keywords. Astiella, endemism, Madagascar, Rubiaceae, Spermacoceae s. lat.

Groeninckx I., Janssens S., Smets E. \& Verstraete B. 2017. Description of 11 new Astiella (Spermacoceae, Rubiaceae) species endemic to Madagascar. European Journal of Taxonomy 312: 1-40. https://doi.org/10.5852/ ejt.2017.312

\section{Introduction}

Madagascar has a unique and spectacularly rich flora with a high percentage of endemism. The island is home to more than 10000 plant species, $90 \%$ of which occur nowhere else in the world, which makes it one of the most important biodiversity hotspots (Moat \& Smith 2007). In Madagascar, Rubiaceae Juss. is the second largest family of flowering plants after Orchidaceae Juss., with currently 751 species in 89 genera (Govaerts et al. 2016). In recent years, several taxonomic works have been completed and in combination with the description of numerous new species, this has resulted in a steadily increase of the total number of Rubiaceae species known from Madagascar (Groeninckx et al. 2010a). Although woody shrubs and trees are most common in Rubiaceae, herbs are present as well and the largest herbaceous 
lineage is the tribe Spermacoceae Cham. \& Schltdl. ex DC. s. lat. (as described in Groeninckx et al. 2010b). According to current estimations, Spermacoceae s. lat. is represented on Madagascar by at least 28 species in 13 genera, of which 9 species and 7 genera are endemic (Govaerts et al. 2016). Astiella Jovet is one of those herbaceous genera endemic to Madagascar (Jovet 1941). The taxonomic position of Astiella remained controversial for a long time but it was eventually placed in Spermacoceae s. lat. close to Phialiphora Groeninckx, Amphistemon Groeninckx, and Thamnoldenlandia Groeninckx, three other herbaceous genera endemic to Madagascar (Janssens et al. 2016). The sole species in the genus, Astiella delicatula Jovet, is characterized by having two calyx lobes, uni-ovulate ovary locules, conspicuous boat-shaped capsules with a well-developed beak, ruminate seeds with a ventral groove, and pluriaperturate pollen (Jovet 1941). During herbarium studies and fieldwork in Madagascar, 11 new Astiella species were identified and these are described here along with an update of the genus description.

\section{Material and methods}

This study of Astiella is based on the examination of herbarium specimens consulted at BR, K, MO, P, and TAN (acronyms following Thiers continuously updated). Additional plant material was obtained during fieldwork in Madagascar. Measurements, colours and other details given in the descriptions are based on pickled and herbarium specimens and data derived from field notes. Each species is illustrated in detail by a line drawing. It should be noted that pubescence is not shown on the habit. Terminology of simple symmetrical plane shapes follows Anonymous (1962). Indumentum terminology follows Beentje (2012). Distribution data is based on specimens from the above-mentioned herbaria. Maps for the Madagascan endemics were made with the software programme iMap (Schols et al. 2001). Habitat delineation is based on Moat \& Smith (2007). Georeferenced specimen data were imported into GeoCAT to calculate area of occupancy (AOO) and extent of occurrence (EOO) for each species (Bachman et al. 2011). The IUCN Red List guidelines recommend a cell width of $2 \mathrm{~km}$ (giving a cell area of $4 \mathrm{~km}^{2}$ ). AOO and EOO results were combined with field observations to produce conservation assessments based on the 2001 IUCN Red List Categories and Criteria (IUCN 2001).

Micromorphological observations were made of pollen and seeds. Pollen grains from herbarium material were acetolysed according to the 'wetting agent' method (Reitsma 1969). Using a scanning electron microscope (SEM), external features were observed on grains that had been suspended in $70 \%$ ethanol and left to dry. Glycerin jelly slides were observed under a light microscope. Polar axis length $(\mathrm{P})$ and equatorial diameter (E) were measured using the software programme Carnoy (Schols et al. 2002). Pollen terminology follows Punt et al. (2007). Seeds from herbarium specimens were directly mounted on aluminium stubs, coated with gold, and observed under the SEM.

\section{Results}

Order Gentianales Juss. ex Bercht. \& J.Presl

Family Rubiaceae Juss. nom. cons.

Subfamily Rubioideae Verdc.

Tribe Spermacoceae Bercht. \& J.Presl

Etymology

Astiella Jovet (Jovet 1941)

Jovet, the author of the genus Astiella, dedicated the genus name to his wife Suzanne Jovet-Ast.

\section{Type species}

Astiella delicatula Jovet. 


\section{Description}

Annual or perennial herb, prostrate or erect, $4-60 \mathrm{~cm}$ tall, sometimes rooting at the nodes; stems quadrangular, glabrous or variously covered with trichomes. Stipules glabrous or pubescent; fimbriae 0-9, 0.1-6.5 mm long, often colleter-tipped. Leaves sessile or petiolate, sometimes anisophyllous, sometimes succulent; petioles $0.4-17 \mathrm{~mm}$ long; blades mostly narrowly elliptic to broadly ovate, rarely linear, $2.2-92 \times 0.5-30.5 \mathrm{~mm}$, glabrous or covered with trichomes, often darker green above, paler green below; base attenuate; apex acuminate, acute or obtuse; margin sometimes revolute when dry, scabrate or ciliolate, rarely glabrous; midvein prominent particularly below; secondary veins prominent or invisible; intersecondaries mostly invisible, sometimes prominent. Inflorescences terminal or pseudo-axillary, single or compound dichasia, 1- to multi-flowered; peduncle $0-56 \mathrm{~mm}$ long, glabrous to pubescent. Pedicels absent or $0.2-16 \mathrm{~mm}$ long, glabrous or pubescent. Flowers predominantly heterostylous, rarely isostylous. Calyx green; tube reduced; lobes 2 or 4, narrowly ovate to broadly ovate or narrowly triangular to triangular, glabrous to densely pubescent, sometimes colleters in between. Corolla mostly white, sometimes pale pink, pale purple or pale blue; tube cylindrical or funnel-shaped, glabrous or pubescent; lobes 4 , mostly narrowly ovate to broadly ovate, sometimes elliptic, ligulate or spatulate, glabrous to pubescent. Stamens inserted near the base of the corolla lobes or in the lower half of the corolla tube, included or exserted. Anthers ellipsoid, rarely broadly obovoid, $0.4-1.8 \mathrm{~mm}$ long; filaments dorsifixed, $0.2-3.3 \mathrm{~mm}$ long. Pollen tri- or pluricolporate, tectum predominantly bireticulate or rarely aperforate. Ovary 2-locular, mostly broadly obovoid to broadly depressed obovoid, sometimes depressed obovoid, broadly obpyramidal or ovoid, glabrous to pubescent; placenta attached near the middle of the septum, predominantly stalked, globose or elongated, bearing 1 to numerous ovules per locule. Style $0.4-6.5 \mathrm{~mm}$ long, included or exserted, mostly glabrous, sometimes hirtellous or papillate; stigma bilobed, lobes $0.1-2.3 \mathrm{~mm}$ long, papillate or hirtellous; nectary disc bipartite. Capsules mostly broadly depressed obovoid, sometimes ovoid, rarely broadly obovoid or subglobose, crowned with the persistent calyx lobes, dehiscence loculicidal. Seeds 1 to numerous per locule, mostly elliptic, rarely ovate or triangular in outline, sometimes dorsiventrally flattened, ventral groove present or absent, black or brown; seed coat surface reticulate or rarely alveolate, testa cells with undulating or straight radial walls, microsculpturing favulariate, granulate, rugulose or verruculate; endosperm sometimes ruminate.

\section{Distribution}

Distributed throughout Madagascar.

\section{Habitat}

Dry forest, humid and sub-humid forest, dunes, savannas, degraded vegetation; calcareous, rocky, laterite, granite or white sand substrate.

\section{Key to the Astiella species}

1. Leaf blades $2.2-4.5 \times 1.1-2.4 \mathrm{~mm}$.......................................... deblockiae Groeninckx sp. nov.

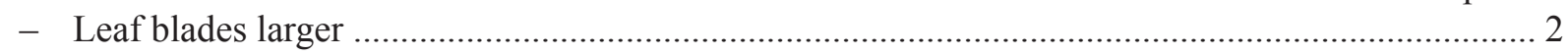

2. Leaf blades linear or narrowly elliptic; secondary veins obscure or invisible ................................ 3

- Leaf blades different; if narrowly elliptic then secondary veins clearly visible, at least below ....... 4

3. Leaf blades linear, $0.7-1.5 \mathrm{~mm}$ wide; flowers sessile .................... A. desseinii Groeninckx sp. nov.

- Narrowly elliptic, $0.5-4.2 \mathrm{~mm}$ wide; flowers pedicellate ................ A. confusa Groeninckx sp. nov.

4. Calyx lobes 2

A. delicatula Jovet

- Calyx lobes 4 
5. Herbs creeping or prostrate, rarely scrambling, rooting at the nodes

- Herbs more or less erect, not or only rooting at the basal nodes

6. Anisophyllous; flowers sessile

A. latifolia Groeninckx sp. nov.

- Isophyllous; flowers pedicellate (pedicel sometimes short) 7

7. Corolla tube usually shorter than the corolla lobes; seeds without ventral groove

- Corolla tube longer than the corolla lobes; seeds with ventral groove

A. perrieri Groeninckx sp. nov. A. tsaratanensis Groeninckx sp. nov.

8. Corolla tube reduced, clearly shorter than corolla lobes 9

- Corolla tube as long or longer than corolla lobes 10

9. Stems pubescent; leaves covered with trichomes below

A. antongilensis Groeninckx sp. nov.

- Stems glabrous or rarely with a few scattered trichomes; leaves glabrous

A. homolleae Groeninckx sp. nov.

10. Stems glabrous or scabrate at the nodes; stipular fimbriae less than $1 \mathrm{~mm}$ long

- Stems covered with long reddish brown multicellular trichomes; stipular fimbriae 4-6.5 mm long A. longifimbria Groeninckx sp. nov.

11. Inflorescence axes slender; 3 ovules per locule; fruits $1-2 \times 1.5-3 \mathrm{~mm}$

A. antsalovansis Groeninckx sp. nov.

- Inflorescence axes more robust; 4-5 ovules per locule; fruits $1.5-3.4 \times 2.6-4 \mathrm{~mm}$

A. pulla Groeninckx sp. nov.

Astiella antongilensis Groeninckx sp. nov.

http://www.ipni.org/urn:lsid:ipni.org:names:77161710-1

Figs 1,2A

\section{Diagnosis}

Astiella antongilensis sp. nov. resembles $A$. homolleae sp. nov. and A. perrieri sp. nov. in having a reduced corolla tube and numerous ovules per locule, but differs in having a pubescent stem, large leaves that are covered with trichomes below, and pubescent flowers.

\section{Etymology}

The epithet refers to Antongil Bay, the largest bay in Madagascar and the area where the species is found.

\section{Type}

MADAGASCAR: Toamasina province, Analanjirofo region, Maroantsetra district. Côte est, environs de la baie d'Antongil, bois, 200 m, Oct. 1912, Perrier de la Bâthie 3749 (holo-: P, P00219825; iso-: P, P00516317).

\section{Description}

Annual herb, ca $10 \mathrm{~cm}$ tall; stems quadrangular in cross section, pubescent. Stipule base $1-2 \mathrm{~mm}$ long, pubescent; fimbriae 3-6, 1-2 mm long, colleter-tipped. Leaves petiolate; petiole 5-15 mm long, pubescent; blades elliptic, slightly ovate or obovate, (12-) $45-72 \times(6-) 10-26 \mathrm{~mm}$, very sparsely covered with trichomes particularly on the veins above, more densely covered with trichomes below; base attenuate; apex acute or obtuse; margin ciliolate; midvein prominent particularly below; secondary veins 


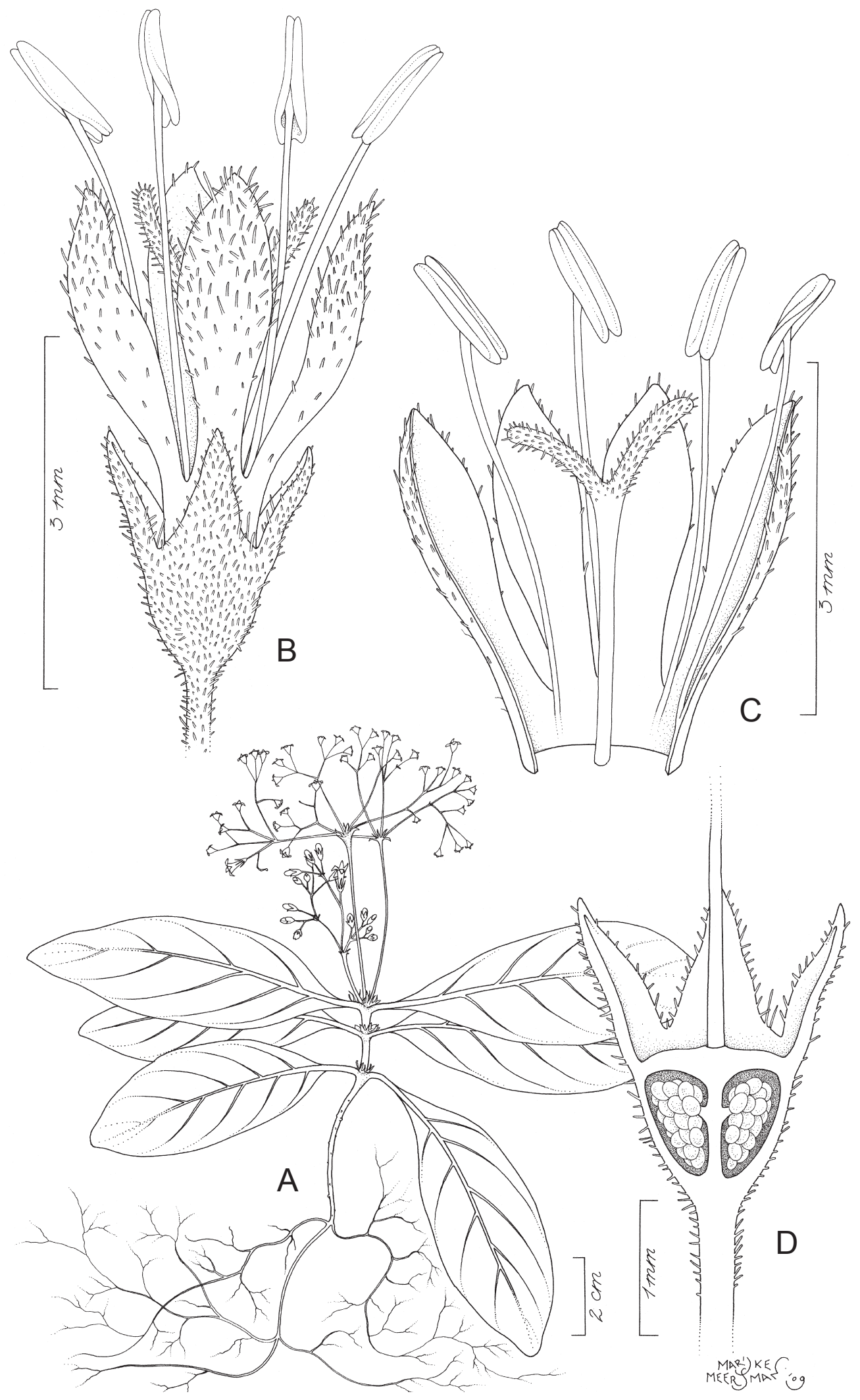

Fig. 1. Astiella antongilensis Groeninckx sp. nov. A. Habit. B. Brevistylous flower. C. Open brevistylous flower. D. Ovary dissected to show placentation. Drawn by Marijke Meersman. All from Perrier de la Bâthie 3749 (P). 

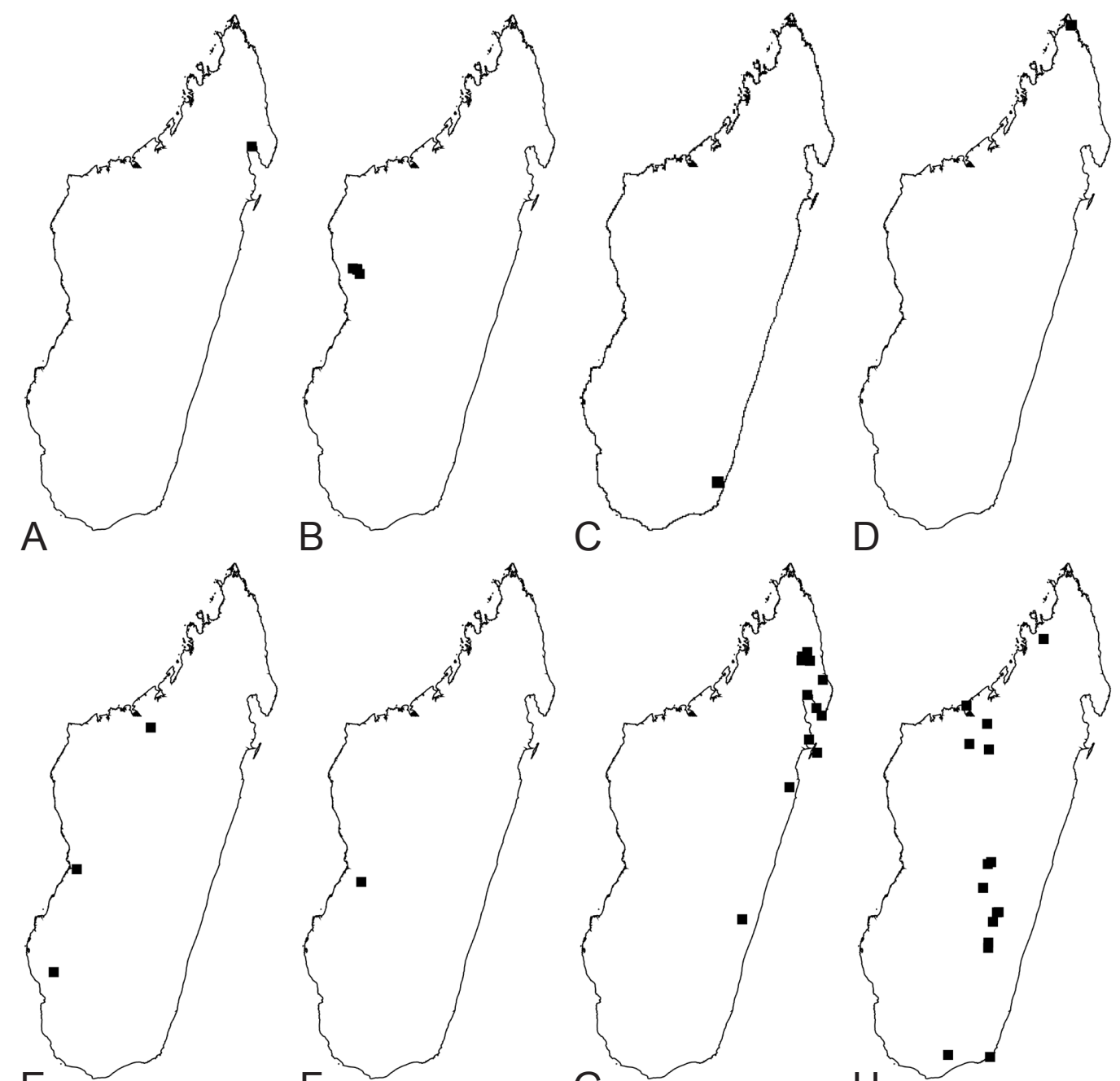

$\mathrm{F}$
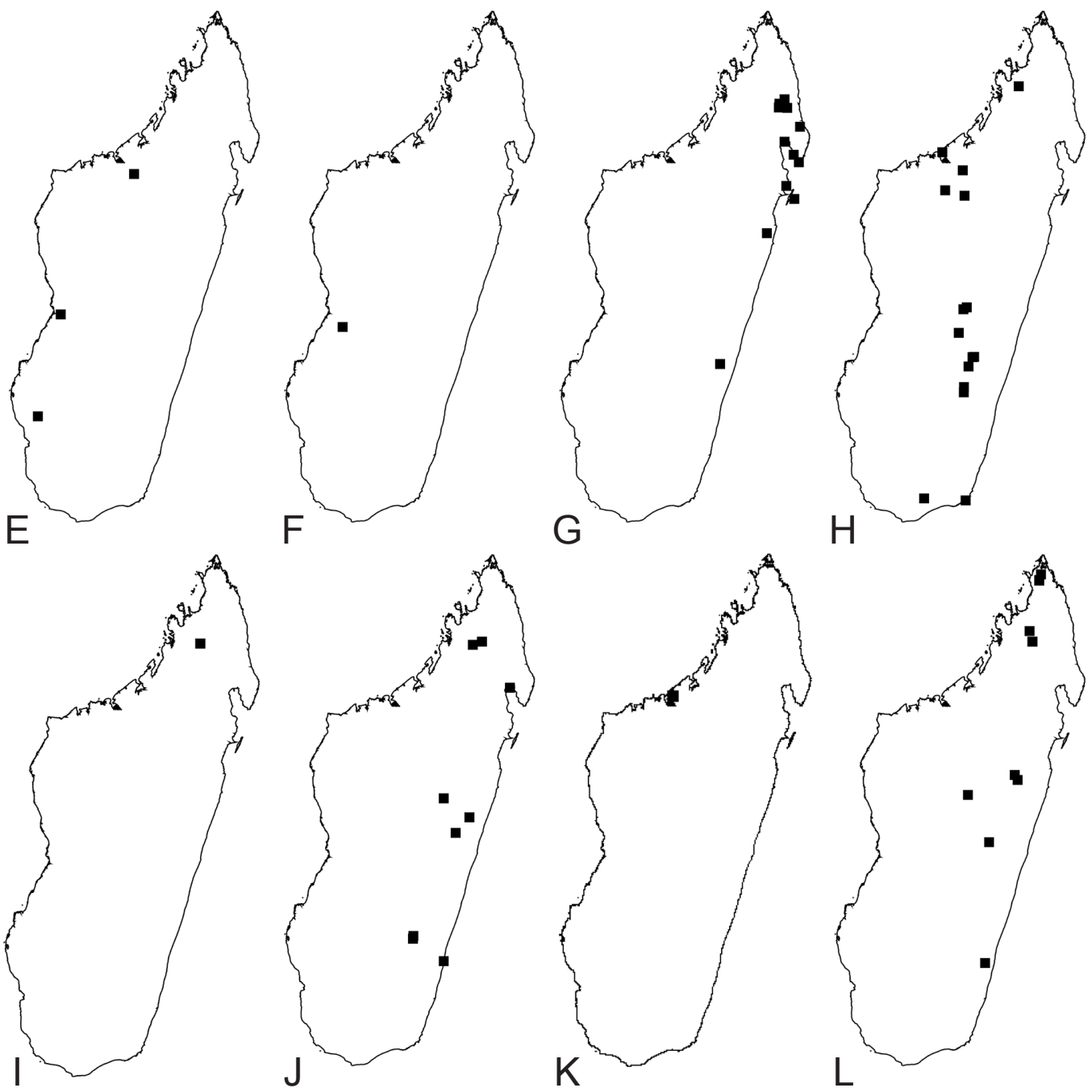

Fig. 2. Distribution maps. A. Astiella antongilensis Groeninckx sp. nov. B. A. antsalovansis Groeninckx sp. nov. C. A. confusa Groeninckx sp. nov. D. A. deblockiae Groeninckx sp. nov. E. A. delicatula Jovet. F. A. desseinii Groeninckx sp. nov. G. A. homolleae Groeninckx sp. nov. H. A. latifolia Groeninckx sp. nov. I. A. longifimbria Groeninckx sp. nov. J. A. perrieri Groeninckx sp. nov. K. A. pulla Groeninckx sp. nov. L. A. tsaratanensis Groeninckx sp. nov. 
4-7 on each side of the midvein; intersecondaries invisible. Inflorescences terminal, multi-flowered; peduncle 0-40 $\mathrm{mm}$ long, pubescent. Pedicels 1-7 mm long, pubescent. Flowers heterostylous (but both style and anthers exserted). Calyx green; tube reduced; lobes 4, narrowly triangular or triangular, $1-1.3 \times 0.4-0.5 \mathrm{~mm}$, pubescent. Corolla white or pale purple; tube reduced, $0.2-0.5 \mathrm{~mm}$ long; lobes 4 , somewhat spathulate, $2.1-2.8 \mathrm{~mm}$ long, $0.5-0.6 \mathrm{~mm}$ wide at the base, $1-1.2 \mathrm{~mm}$ wide at the top, pubescent outside, papillate inside. Stamens inserted near the base of the corolla lobes and exserted for 2.2-3.2 $\mathrm{mm}$ beyond the corolla throat. Anthers ellipsoid, 1.2-1.4 $\mathrm{mm}$ long; filaments dorsifixed, ca $3.3 \mathrm{~mm}$ long in brevistylous flowers, ca $1.2 \mathrm{~mm}$ long in longistylous flowers. Pollen unknown. Ovary 2-locular, broadly obovoid, $1-1.2 \times 1-1.3 \mathrm{~mm}$, densely pubescent; placenta attached above the middle of the septum, stalked, elongated, bearing numerous ovules per locule. Style ca $3.3 \mathrm{~mm}$ long in longistylous flowers (exserted for ca $3 \mathrm{~mm}$ beyond the corolla throat), ca $2.5 \mathrm{~mm}$ long in brevistylous flowers (exserted for ca $2.2 \mathrm{~mm}$ beyond the corolla throat), glabrous; stigma bilobed, lobes $0.6-1 \mathrm{~mm}$ long, papillate. Capsules broadly obovoid or broadly depressed obovoid, $2.5-3 \times 2.5-3 \mathrm{~mm}$, crowned with the persistent calyx lobes, pubescent, dehiscence loculicidal. Seeds unknown.

\section{Distribution}

E Madagascar: Toamasina province, Analanjirofo region, Maroantsetra district.

\section{Habitat}

Humid forest; at $200 \mathrm{~m}$ elevation.

\section{Conservation status}

The species is only known from its type collected in 1912. There is no detailed information about the locality where the specimen was collected. Given its apparent rarity and following the recommendation of Callmander et al. (2005) to avoid the Data Deficient category, we consider the species as vulnerable (VU D2) based on its restricted area of occupancy (D2) and the high human pressure present in the entire area resulting in a general decline of suitable habitats (humid forest) for the species.

Astiella antsalovansis Groeninckx sp. nov. http://www.ipni.org/urn:1sid:ipni.org:names:77161713-1 Figs 2B, 3, 4A, 5A-B

\section{Diagnosis}

Astiella antsalovansis sp. nov. resembles $A$. pulla sp. nov. in having black seeds with a reticulate seed coat surface consisting of 5- to 6-angular testa cells and in having a ring of trichomes inside the corolla tube, but differs in the slender inflorescence axes (vs more robust), 3 ovules per locule (vs 4 to 5 ovules per locule), and a shorter style that is included in brevistylous flowers (vs exserted), and fruits $1-2 \times$ $1.5-3 \mathrm{~mm}$ (vs $1.5-3.4 \times 2.6-4 \mathrm{~mm})$.

\section{Etymology}

The specific epithet refers to the Antsalova district where representative specimens were collected.

\section{Type}

MADAGASCAR: Mahajanga province, Melaky region, Antsalova district. Antsalova, 23 Feb. 1959, Botoalina 10301-RN (holo-: P; iso-: $\mathrm{BR}$ ).

\section{Additional material examined}

MADAGASCAR: Mahajanga province, Melaky region, Antsalova district. Antsingy d'Antsalova, RN 9, en sous bois de forêt tropophile sur calcaire, Jan. 1975, Morat 4805 (P, TAN); $14 \mathrm{~km}$ ouest de 


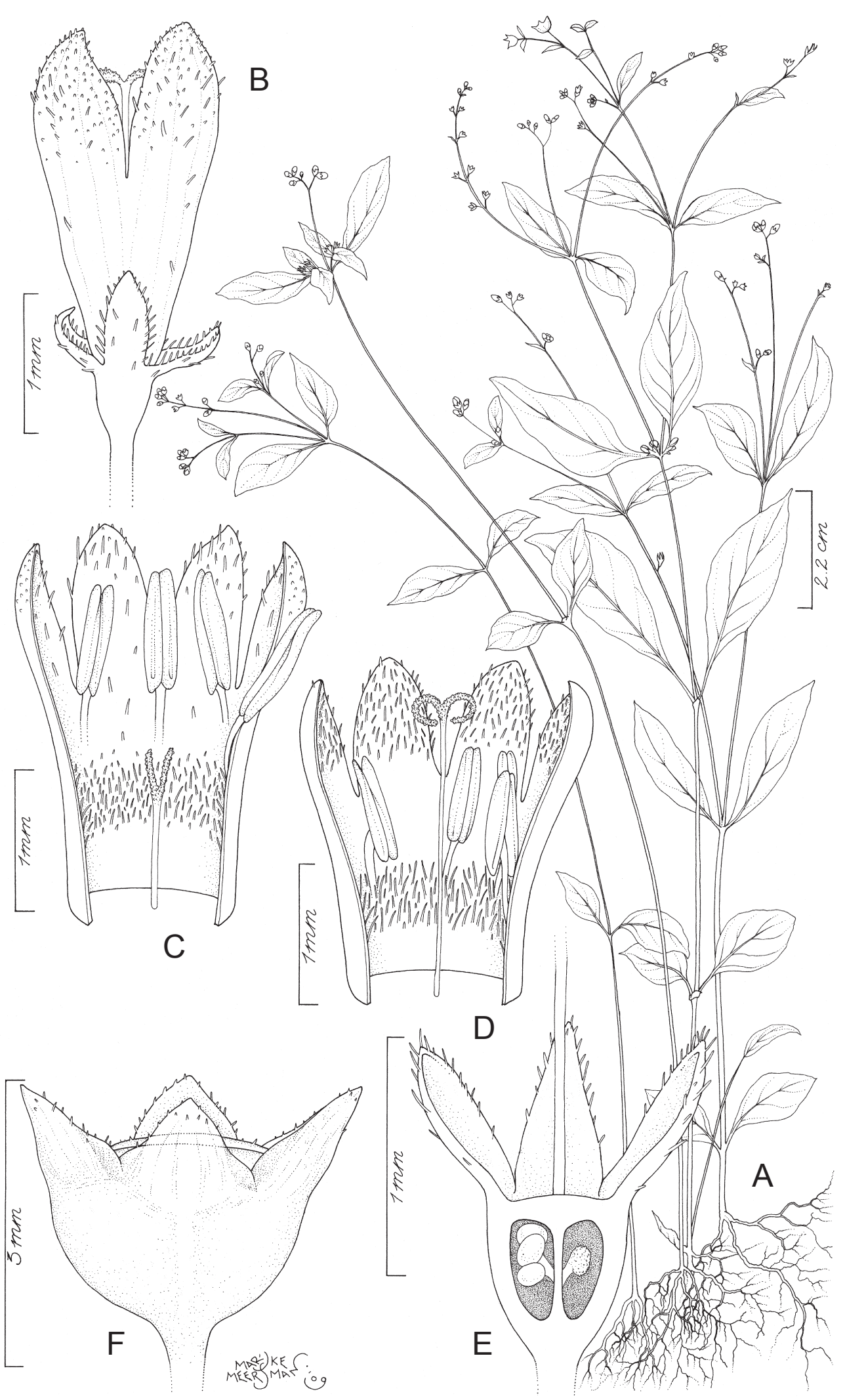

Fig. 3. Astiella antsalovansis Groeninckx sp. nov. A. Habit. B. Longistylous flower. C. Open brevistylous flower. D. Open longistylous flower. E. Ovary dissected to show placentation. F. Capsule. Drawn by Marijke Meersman. A-E from Morat 4805 (P); F from Villiers, Klackenberg \& Badre 4788 (P). 
Antsalova, sur dalle rocheuse en sous-bois, 17 Mar. 1993, Villiers, Klackenberg \& Badre 4788 (P); $12 \mathrm{~km}$ ESE Ankiliromotsy, $26 \mathrm{~km}$ SE Antsalova, sous couvert forêt tropophile, 30 Mar. 1993, Villiers, Klackenberg \& Badre 4996 (P).

\section{Description}

Annual herb, erect, up to $30 \mathrm{~cm}$ tall; stems quadrangular in cross section, only sparsely branching, glabrous or scabrate particularly at the nodes. Stipule base $0.5-1 \mathrm{~mm}$ long, puberulent; fimbriae $4-6$, 0.1-0.4 mm long, colleter-tipped. Leaves petiolate; petioles $1-15 \mathrm{~mm}$ long, glabrous or scabrate; blades narrowly ovate to ovate, $10-60 \times 3.5-30.5 \mathrm{~mm}$, glabrous or sparsely to densely scabrate particularly on the veins and towards the margin; base attenuate; apex acute; midvein prominent particularly below; secondary veins 3-6 on each side of the midvein, prominent below; intersecondaries visible. Inflorescences terminal or pseudo-axillary, lax compound dichasia, multi-flowered, resembling a scorpioid cyme, rarely axillary and then few-flowered and compact; peduncle $0-56 \mathrm{~mm}$ long, glabrous or scabrate; inflorescence axes slender. Pedicels absent or $0.5-2 \mathrm{~mm}$ long, glabrous or scabrate. Flowers heterostylous. Calyx green; tube reduced; lobes 4, triangular, $1-2 \times 0.2-0.5 \mathrm{~mm}$, sparsely to densely scabrate or covered with long trichomes, particularly on the margin. Corolla white, pale pink in the throat; tube funnel-shaped, $0.9-1.5 \mathrm{~mm}$ long, $0.4-0.6 \mathrm{~mm}$ wide at the base and $0.5-0.8 \mathrm{~mm}$ wide at
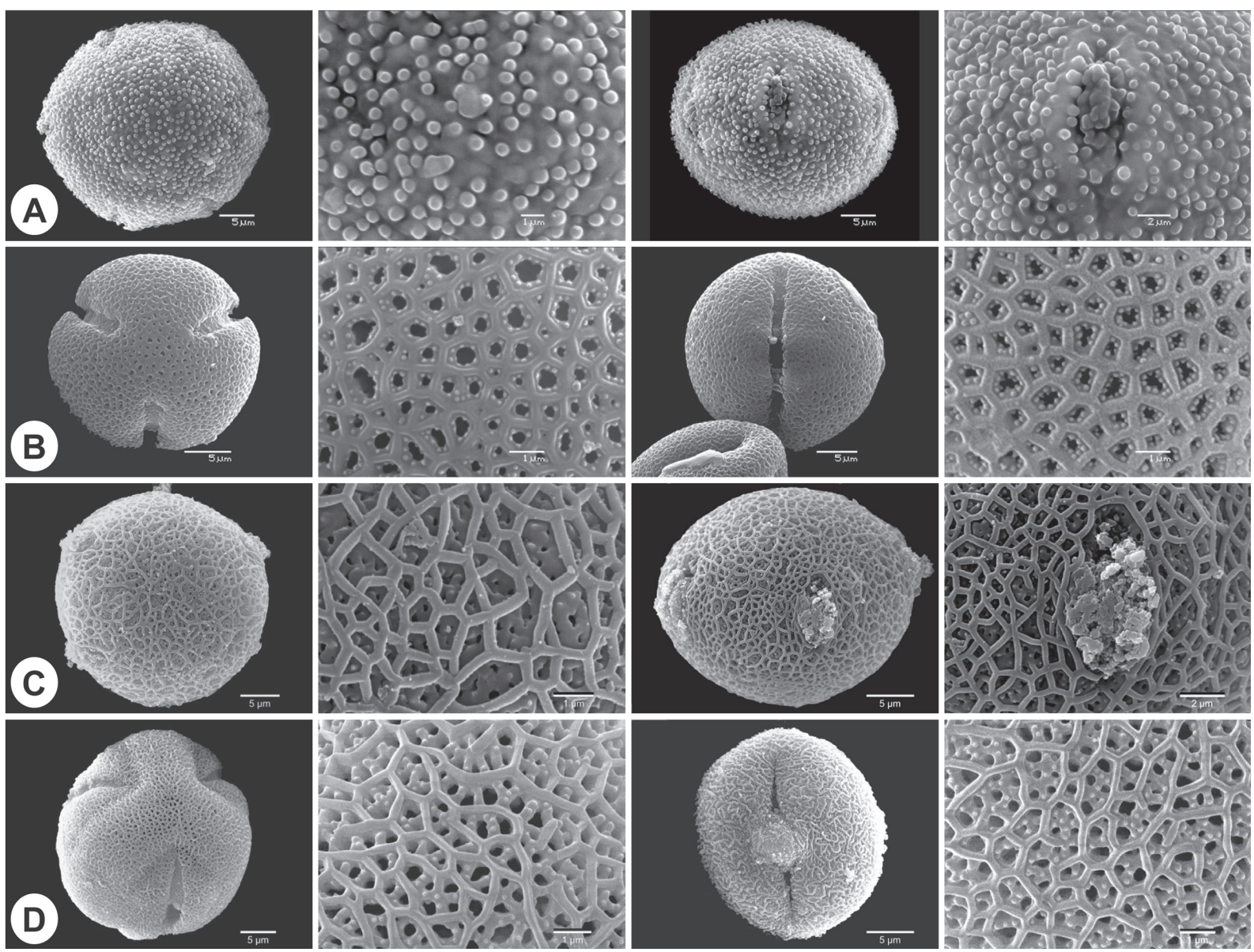

Fig. 4. Scanning electron microscopy micrographs of pollen in polar view (PV), the apocolpium (AC), pollen in equatorial view (EV) and the mesocolpium (ME). A. Astiella antsalovansis Groeninckx sp. nov. B. A. deblockiae Groeninckx sp. nov. C. A. delicatula Groeninckx sp. nov. D. A. desseinii Groeninckx sp. nov. Scale bars for A and C: PV, $\mathrm{EV}=5 \mu \mathrm{m}, \mathrm{AC}=1 \mu \mathrm{m}, \mathrm{ME}=2 \mu \mathrm{m}$; for B and D: PV, $\mathrm{EV}=5 \mu \mathrm{m}$, $\mathrm{AC}, \mathrm{ME}=1 \mu \mathrm{m}$. 


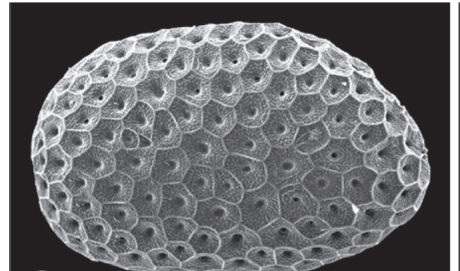

(A)
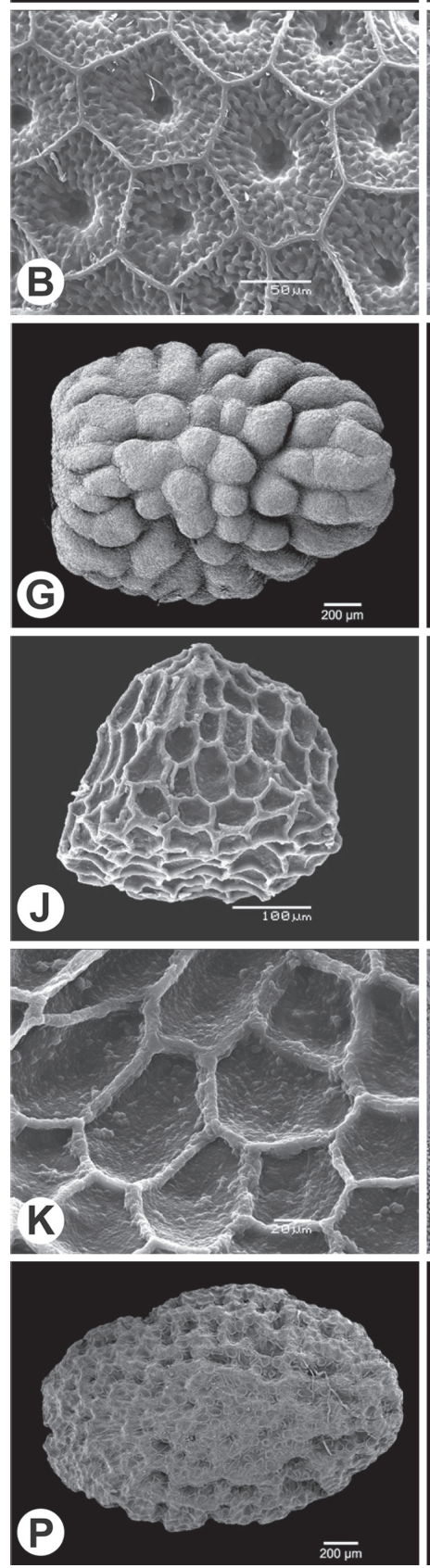
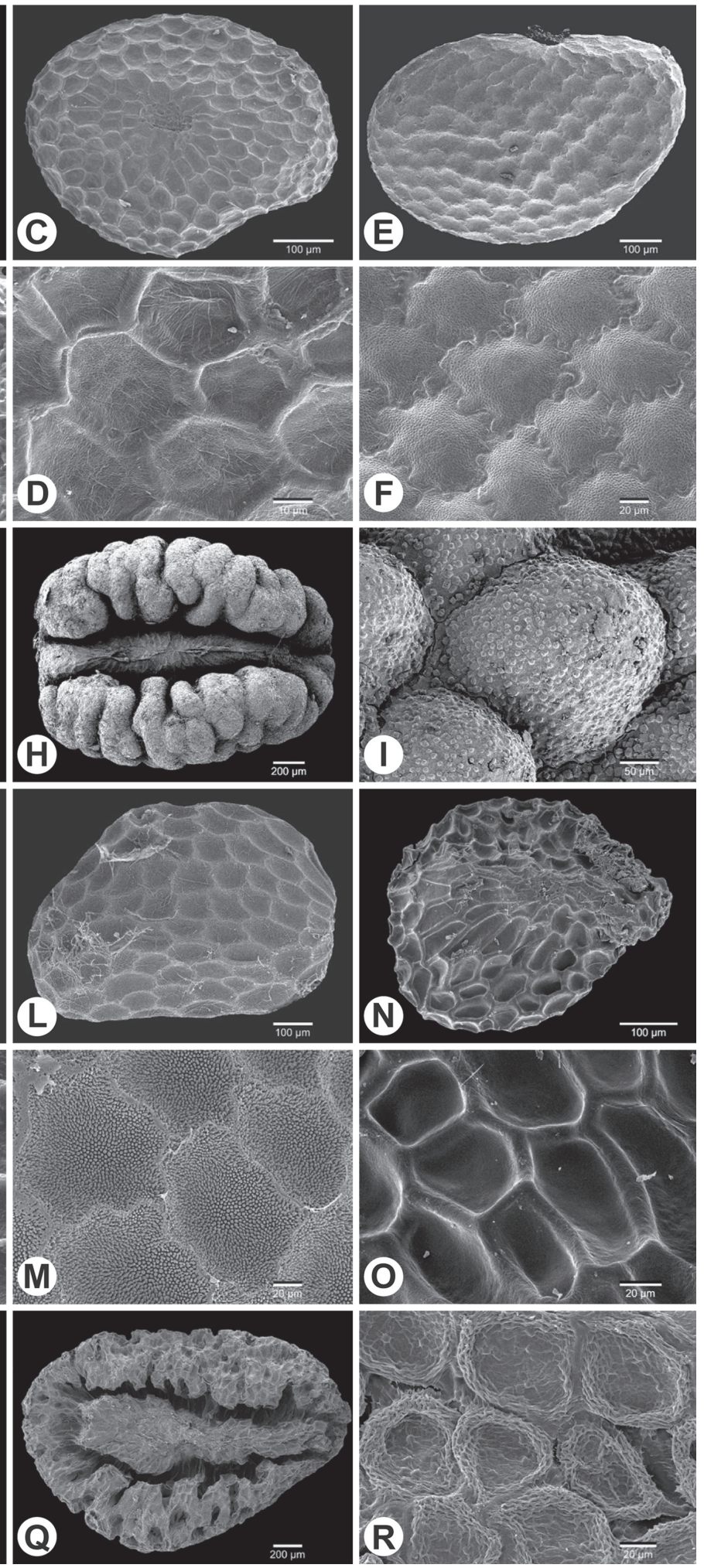

Fig. 5. Scanning electron microscopy micrographs of seeds and a detail of their surface. A-B. Astiella antsalovansis Groeninckx sp. nov. C-D. A. deblockiae Groeninckx sp. nov. E-F.A. desseinii Groeninckx sp. nov. G-I. A. delicatula Jovet. J-K. A. homolleae Groeninckx sp. nov. L-M. A. latifolia Groeninckx sp. nov. N-O. A perrieri Groeninckx sp. nov. P-R. A. tsaratanensis Groeninckx sp. nov. Scale bars for A, C, E, J, L, N = $100 \mu \mathrm{m} ; \mathrm{B}, \mathrm{I}=50 \mu \mathrm{m} ; \mathrm{D}=10 \mu \mathrm{m} ; \mathrm{F}, \mathrm{K}, \mathrm{M}, \mathrm{O}, \mathrm{R}=20 \mu \mathrm{m} ; \mathrm{G}, \mathrm{H}, \mathrm{P}, \mathrm{Q}=200 \mu \mathrm{m}$. 
the throat, with a few trichomes outside, with a ring of trichomes inside; lobes 4 , ligulate, 1.3-1.6 $\times$ $0.5-0.6 \mathrm{~mm}$ in brevistylous flowers, $0.8-1.2 \times 0.4-0.5 \mathrm{~mm}$ in longistylous flowers, glabrous outside, covered with trichomes inside. Stamens inserted near the base of the corolla lobes and exserted for ca $1 \mathrm{~mm}$ beyond the corolla throat in brevistylous flowers, inserted in the lower half of the corolla tube and included or only the apices exserted in longistylous flowers. Anthers ellipsoid, $0.7-1 \mathrm{~mm}$ long; filaments dorsifixed, ca $0.5 \mathrm{~mm}$ long in brevistylous flowers, $0.3-0.4 \mathrm{~mm}$ long in longistylous flowers. Pollen 7-colporate, suboblate; E 32-33 $\mu \mathrm{m}$; P 28-31 $\mu \mathrm{m}$; ectocolpi short; endocolpi short; tectum aperforate, granulate. Ovary 2-locular, broadly obpyramidal, $0.4-0.7 \times 0.4-0.5 \mathrm{~mm}$, glabrous or with a few trichomes; placenta attached near the middle of the septum, stalked, globose, bearing 3 ovules per locule. Style 1-1.2 $\mathrm{mm}$ long and included in brevistylous flowers, $1.8-2 \mathrm{~mm}$ long and exserted for $0.7-0.8 \mathrm{~mm}$ beyond the corolla throat in longistylous flowers, glabrous; stigma bilobed, lobes $0.2-0.3$ $\mathrm{mm}$ long, papillate, pale blue. Capsules broadly depressed obovoid, $1-2 \times 1.5-3 \mathrm{~mm}$, crowned with the persistent calyx lobes, glabrous, dehiscence loculicidal. Seeds 1 per locule, elliptic in outline, ventral groove absent, $0.7-1 \times 0.5-0.6 \mathrm{~mm}$, black; seed coat surface reticulate, 5- to 6-angular testa cells, microsculpturing verruculate, central pit in tangential wall.

\section{Distribution}

W Madagascar: Mahajanga province, Melaky region, Antsalova district.

\section{Habitat}

Western humid and sub-humid forest; calcareous or rocky substrate.

\section{Vernacular name}

Masonkary.

\section{Conservation status}

The species is known from four localities from the Antsalova district. It is probable that the species grows within the Tsingy de Bemaraha National Park. The extent of occurrence is estimated between 100 and $5,000 \mathrm{~km}^{2}$. The area of occupancy is estimated between 10 and $500 \mathrm{~km}^{2}$. The number of locations is two: i.e. populations within the protected area and populations outside the protected area. The human pressure on the environment within the region is very high. A decline in the extent of occurrence, area of occupancy, and area, extent, and/or quality of habitat is therefore very likely. The species is therefore considered endangered: EN B1ab(i,ii,iii)+2ab(i,ii,iii).

Astiella confusa Groeninckx sp. nov. http://www.ipni.org/urn:1sid:ipni.org:names:77161715-1

Figs $2 \mathrm{C}, 6$

\section{Diagnosis}

Astiella confusa sp. nov. resembles A. tsaratanensis sp. nov. in having few ovules per locule, broadly depressed obovoid capsules crowned with the persistent calyx lobes, and black seeds that are elliptic in outline and have a ventral groove, but differs in its erect habit (vs scrambling or prostrate), the much shorter corolla tube (1.5-1.7 $\mathrm{mm}$ vs $4.8-9.5 \mathrm{~mm}$ long), the tricolporate pollen (vs 7- to 8-colporate), and the reticulate seed coat surface with favulariate microsculpturing (vs an alveolate seed surface with rugulose microsculpturing).

\section{Etymology}

The specific epithet is the feminine participle of the Latin verb 'confundo', meaning 'to confuse', and refers to the fact that this species has been confused with $A$. delicatula. 


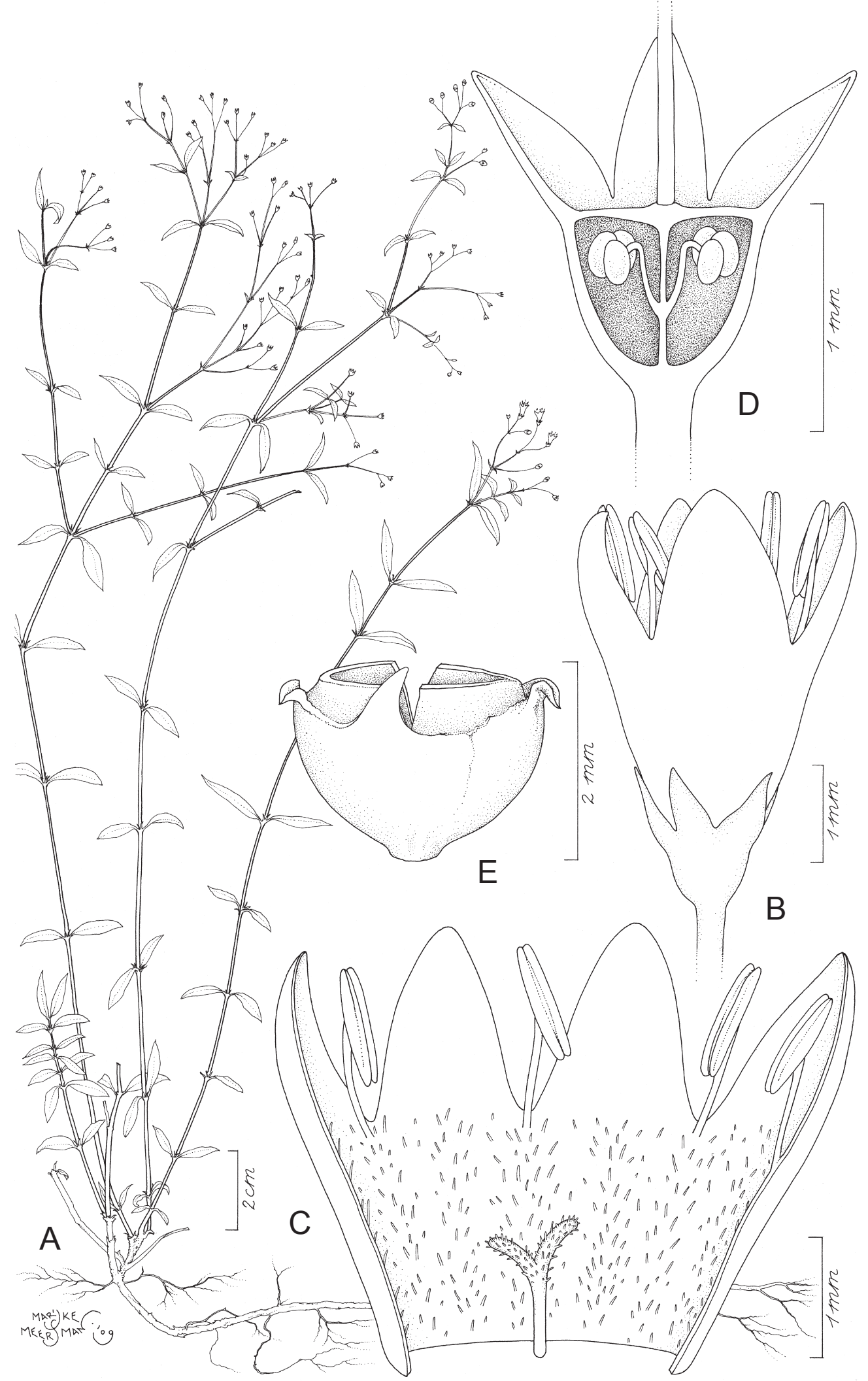

Fig. 6. Astiella confusa Groeninckx sp. nov. A. Habit. B. Brevistylous flower. C. Open brevistylous flower. D. Ovary dissected to show placentation. E. Capsule. Drawn by Marijke Meersman. All from Humbert 20713 (BR). 
Type

MADAGASCAR: Toliara province, Anosy region, Taolanaro district. Bassin de la Manampanihy (sud est), mont Vohimavo au nord d'Ampasimena, rochers du sommet, forêt ombrophile sur argiles latériques et granite, 830 m, 27-28 Mar. 1947, Humbert 20713 (holo-: BR; iso-: MO).

\section{Description}

Herb, up to $60 \mathrm{~cm}$ tall; stems quadrangular in cross section, glabrous. Stipule base $0.5-1.5 \mathrm{~mm}$ long, pubescent; fimbriae usually bifid, $0.4-1.2 \mathrm{~mm}$ long, colleter-tipped. Leaves sessile; blades narrowly elliptic, $2.5-20 \times 0.5-4.2 \mathrm{~mm}$, glabrous or scabrate, darker green above, paler green below; base attenuate; apex acute; margin revolute when dry; midvein prominent or invisible above, always prominent below; secondary veins invisible or 1-2 on each side of the midvein; intersecondaries invisible. Inflorescences terminal, compound dichasia, several-flowered; peduncle 0-12 mm long, glabrous. Pedicels (0.7-)3$9.5 \mathrm{~mm}$ long, scabrate. Flowers probably heterostylous (only flowers with anthers exserted and style included were observed). Calyx green; tube reduced; lobes 4, triangular, 0.7-1 $\times 0.4-0.6 \mathrm{~mm}$, glabrous to scabrate. Corolla white; tube funnel-shaped, $1.5-1.7 \mathrm{~mm}$ long, glabrous outside and pubescent inside; lobes 4, ovate, 1.5-1.6 $\times 0.8-1 \mathrm{~mm}$, glabrous. Stamens inserted near the base of the corolla lobes and exserted for ca $2 \mathrm{~mm}$ beyond the corolla throat. Anthers ellipsoid, $0.8-1 \mathrm{~mm}$ long; filaments dorsifixed, 1.4-1.7 mm long. Pollen tricolporate. Ovary 2-locular, broadly obovoid to broadly depressed obovoid, $0.5-0.7 \times 0.7-1 \mathrm{~mm}$, glabrous; placenta attached near the middle of the septum, stalked, globose, bearing few (3-4) ovules per locule. Style 1.2-1.3 mm long, included, glabrous; stigma bilobed, lobes 0.3-0.4 mm long, papillate to hirtellous. Capsules broadly depressed obovoid, well-developed beak, $1.2-1.4 \times 2.3-2.7 \mathrm{~mm}$, crowned with the persistent calyx lobes, glabrous, dehiscence loculicidal. Seeds few $(2-3)$, elliptic in outline, ventral groove present, $0.8-1 \times 0.6-0.8 \mathrm{~mm}$, black; seed coat surface reticulate, microsculpturing favulariate.

\section{Distribution}

SE Madagascar: Toliara province, Anosy region, Taolanaro district.

\section{Habitat}

Humid forest; laterite and granite substrate; at $830 \mathrm{~m}$ elevation.

\section{Conservation status}

Known from only one locality. Given its apparent rarity and following the recommendation of Callmander et al. (2005) to avoid the Data Deficient category, we consider the species as vulnerable (VU D2) based on its restricted area of occupancy (D2) and the high human pressure present in the entire area resulting in a general decline of suitable habitats (humid forest) for the species.

Astiella deblockiae Groeninckx sp. nov. http://www.ipni.org/urn:lsid:ipni.org:names:77161717-1

Figs 2D, 4B, 5C-D, 7

\section{Diagnosis}

Astiella deblockiae sp. nov. resembles A. desseinii sp. nov. and A. latifolia sp. nov. in having tricolporate pollen and numerous ovules per locule, but differs in having a small habit ( $5 \mathrm{~cm}$ vs $10-25 \mathrm{~cm}$ tall), very small leaves $(2.2-4.5 \mathrm{~mm}$ vs $3.2-20(-30) \mathrm{mm}$ long), small corolla tubes $(1.5-2.2 \mathrm{~mm}$ vs $3.5-11$ $\mathrm{mm}$ long), small capsules (1.4-2 $\mathrm{mm}$ vs $3-4.5 \mathrm{~mm}$ long), and dorsiventrally flattened seeds (vs not flattened). 


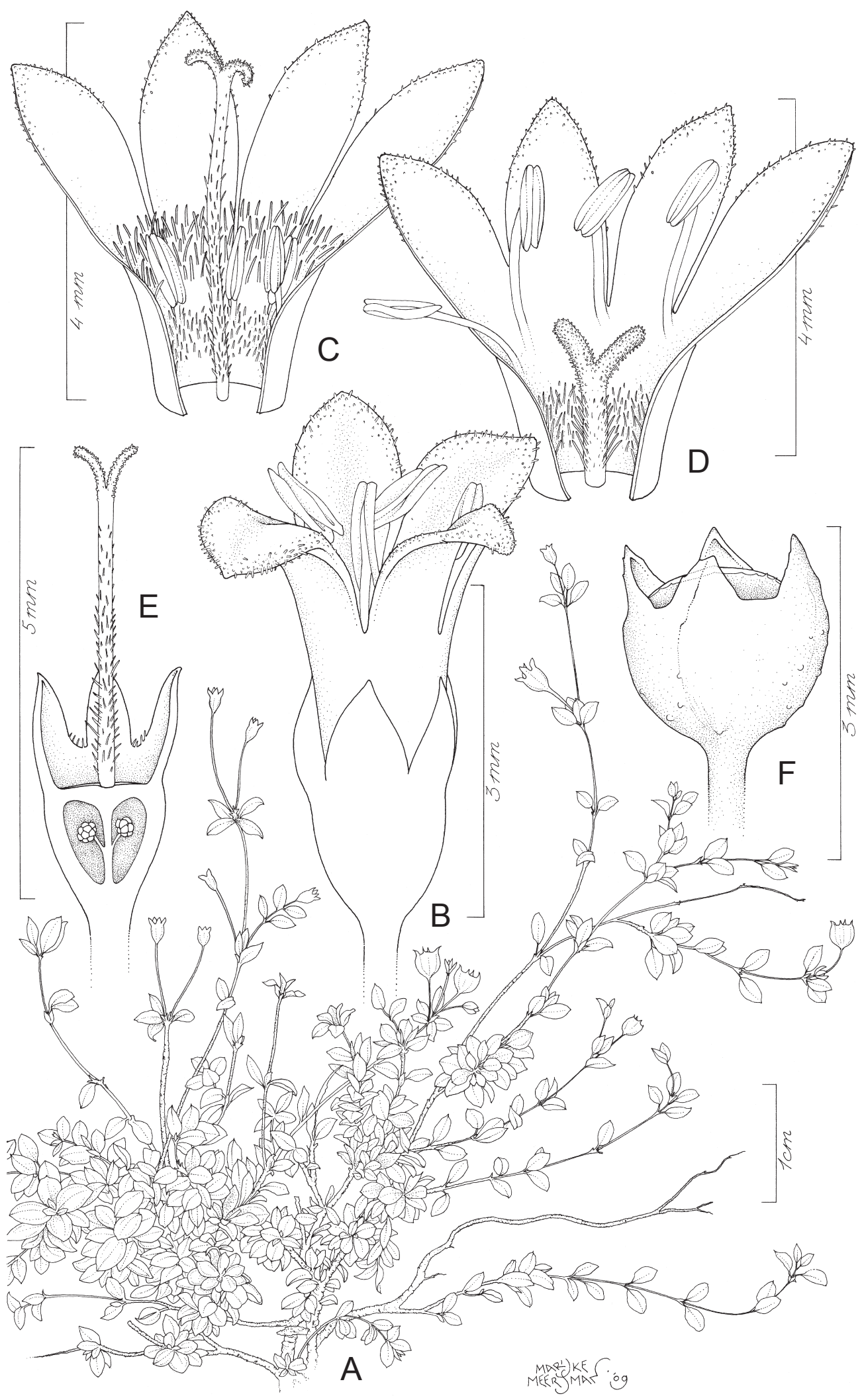

Fig. 7. Astiella deblockiae Groeninckx sp. nov. A. Habit. B. Brevistylous flower. C. Open longistylous flower. D. Open brevistylous flower. E. Ovary dissected to show placentation. F. Capsule. Drawn by Marijke Meersman. All from De Block, Rakotonasolo \& Randriamboavonjy 1303 (BR). 


\section{Etymology}

The species is named in honour of Dr. Petra De Block, who collected it at the Baies de Sakalaves and who played an important role in making the inventory of Madagascan Rubiaceae.

\section{Type}

MADAGASCAR: Antsiranana province, Diana region, Antsiranana I district, Baies de Sakalaves, dunes not far from the beach, low herbaceous vegetation, white sand, 19 Jan. 2002, De Block, Rakotonasolo \& Randriamboavonjy 1303 (holo-: BR; iso-: $\mathrm{BR}, \mathrm{K}, \mathrm{MO}, \mathrm{P}, \mathrm{TAN}$ ).

\section{Additional material examined}

MADAGASCAR: Antsiranana province, Diana region, Antsiranana I district, Diégo-Suarez, Orangea, en coussinets sur le sable, bord de la mer, 16 Apr. 1970, Bosser 20203 (P); Sud de la forêt d'Orangea, environs de Diégo-Suarez, 24 Nov. 1970, Keraudren-Aymonin \& Aymonin 25500 (P).

\section{Description}

Perennial herb, prostrate, ca $5 \mathrm{~cm}$ tall, somewhat succulent; stems quadrangular in cross section, somewhat lignified at the base, glabrous or scabrate, brown. Stipule base $0.4-0.8 \mathrm{~mm}$ long, beset with a few trichomes; fimbriae 2-4, 0.1-0.7 mm long. Leaves petiolate, succulent; petioles $0.4-1 \mathrm{~mm}$ long, ciliate; blades ovate, broadly ovate or elliptic, $2.2-4.5 \times 1.1-2.4 \mathrm{~mm}$, glabrous except for ciliate margin at the base of the leaf; base attenuate; apex shortly acuminate or acute; margin revolute when dry; midvein prominent below; secondary veins invisible; intersecondaries invisible. Inflorescences pseudo-axillary, mostly 1- to 3-flowered; peduncle absent. Pedicels 1-11 mm long, glabrous. Flowers heterostylous. Calyx green; tube reduced; lobes 4 , ovate to broadly ovate, $0.6-1 \times 0.5-1 \mathrm{~mm}$, glabrous, colleters and a few trichomes in between the lobes. Corolla pale pink; tube cylindrical, $1.5-2.2 \times 0.6-1.4 \mathrm{~mm}$ in brevistylous flowers, $0.8-1 \times 1.2 \mathrm{~mm}$ in longistylous flowers, glabrous outside, with a ring of trichomes (ca $0.3 \mathrm{~mm}$ long) at the lower half inside; lobes 4, narrowly ovate or ovate, $1.4-2.5 \times 0.7-1 \mathrm{~mm}$, glabrous outside, papillose inside, with a ring of spreading trichomes (ca $0.5 \mathrm{~mm}$ long) at the base inside in longistylous flowers. Stamens inserted near the base of the corolla lobes, exserted for 1-1.8 $\mathrm{mm}$ beyond the corolla throat in brevistylous flowers, exserted for $0.4-0.6 \mathrm{~mm}$ beyond the corolla throat in longistylous flowers. Anthers ellipsoid, $0.7-0.8 \mathrm{~mm}$ long; filaments dorsifixed, ca $1 \mathrm{~mm}$ long in brevistylous flowers, ca $0.2 \mathrm{~mm}$ long in longistylous flowers. Pollen tricolporate, oblate spheroidal to prolate spheroidal; E 24-26 $\mu \mathrm{m}$; P 23-25 $\mu \mathrm{m}$; ectocolpi long; endocolpi unknown; tectum bireticulate; suprareticulum microreticulate to reticulate; infrareticulum present as granules in the lumina of the suprareticulum. Ovary 2-locular, broadly obovoid to broadly depressed obovoid, $0.7-1.2 \times 0.8-1.5 \mathrm{~mm}$, glabrous to sparsely pubescent; placenta attached near the middle of the septum, stalked, globose, bearing numerous ovules per locule. Style ca $1.5 \mathrm{~mm}$ long and included or only with the stigma tips exserted beyond the corolla throat in brevistylous flowers, $2-3.5 \mathrm{~mm}$ long and exserted for $1.3-1.7 \mathrm{~mm}$ beyond the corolla throat in longistylous flowers, hirtellous; stigma bilobed, lobes ca $0.5 \mathrm{~mm}$ long in brevistylous flowers, $0.3-0.5 \mathrm{~mm}$ long in longistylous flowers, papillate. Capsules subglobose, $1.4-2 \times$ $1.8-2 \mathrm{~mm}$, crowned with persistent calyx lobes, glabrous, dehiscence loculicidal. Seeds numerous per locule, ovate in outline, dorsiventrally flattened, ventral groove absent, $0.4-0.5 \times 0.2-0.4 \mathrm{~mm}$, brown; seed coat surface reticulate, microsculpturing rugulose.

\section{Distribution}

N Madagascar: Antsiranana province, Diana region, Antsiranana I district.

\section{Habitat}

Dunes close to the sea; white sand substrate. 


\section{Conservation status}

The species is known from three collections at two localities representing two different locations. The extent of occurrence could not be calculated because there are only two sets of lat/long coordinates. The area of occupancy is estimated smaller than $10 \mathrm{~km}^{2}$. The main threat for the species is the high human pressure in some areas where the species occurs. A decline in the extent of occurrence, area of occupancy, and area, extent, and/or quality of habitat is therefore very likely. Therefore the species is considered endangered: EN B1ab(i,ii,iii)+2ab(i,ii,iii).

\section{Astiella delicatula Jovet}

Figs 2E, 4C, 5G-I, 8

\section{Etymology}

The specific epithet is based on the Latin adjective 'delicatus', meaning 'delicate', referring to the slender habit of the species.

\section{Type}

MADAGASCAR: Toliara province, Atsimo-Andrefana region, Sakaraha district, Forêt d'Analafanja au nord du Fiherenana, plateau calcaire, Mar. 1934, Humbert 14296 (holo-: P).

\section{Additional material examined}

MADAGASCAR: Toliara province, Atsimo-Andrefana region, Sakaraha district, Sous bois forêt tropophile, forêt du Zombitsy, Sakaraha, Mar. 1964, Bosser 19364 (BR). Menabe region, Morondava district, Kirindi forest, north part, piste de pointe de vue $\mathrm{km} \mathrm{7,} \mathrm{on} \mathrm{road} \mathrm{through} \mathrm{dry} \mathrm{forest,} \mathrm{white} \mathrm{sand,} 19$ Jan. 2007, De Block et al. 2173 (BR, MO, P, TAN). Mahajanga province, Boeny region, Ambato Boeni district, RN d'Ankarafantsika, 21 Mar. 2010, De Block et al. 2369 (BR, MO, P, TAN).

\section{Description}

Annual herb, up to $23 \mathrm{~cm}$ tall; stems quadrangular in cross section, only sparsely branching, puberulous, green tinged reddish. Stipule base $0.7-1 \mathrm{~mm}$ long, puberulous, slightly tinged red; fimbriae 3-4, 0.5-1.5 mm long, beset with a few trichomes, with colleters in between. Leaves petiolate; petioles $1.5-4 \mathrm{~mm}$ long, puberulous; blades ovate at the basal portion of the stem, $9.5-14.5 \times 4.5-8.5 \mathrm{~mm}$, narrowly ovate at the distal portion of the stem, $24-50 \times 9-15.2 \mathrm{~mm}$, with a few trichomes particularly on the veins, darker green above, paler green below; base obtuse, attenuate or unequal; apex acuminate; margin scabrate; midvein prominent; secondary veins 3-6 on each side of the midvein, prominent; intersecondaries prominent. Inflorescences terminal or pseudo-axillary, single or compound dichasia, 3- to several-flowered, somewhat resembling a scorpioid cyme; peduncle $6.5-21.5 \mathrm{~mm}$ long, sparsely puberulous. Pedicels $0.2-4.5 \mathrm{~mm}$ long, glabrous or puberulous. Flowers isostylous. Calyx green; tube reduced; lobes 2 , narrowly ovate, $1.1-4 \times 0.2-0.3 \mathrm{~mm}$, scabrate. Corolla white; tube cylindrical, $1.6-1.8 \times 0.5-0.7 \mathrm{~mm}$, glabrous; lobes 4 , ovate, $0.7-1 \times 0.4-0.6 \mathrm{~mm}$, glabrous. Stamens inserted in the lower half of the corolla tube and included. Anthers ellipsoid, $0.4-0.5 \mathrm{~mm}$ long; filaments dorsifixed, ca $0.2 \mathrm{~mm}$ long. Pollen 5- or 6-colporate, suboblate; E 27-28 $\mu \mathrm{m}$; P $23-28 \mu \mathrm{m}$; ectocolpi short; endocolpi short; tectum bireticulate; suprareticulum microreticulate to reticulate, smooth; infrareticulum perforate with granules. Ovary 2-locular, depressed obovoid, $0.3-0.5 \times 0.6-0.8 \mathrm{~mm}$, glabrous; placenta attached near the middle of the septum, stalked, globose, bearing 1 ovule per locule. Style $0.4-0.5 \mathrm{~mm}$ long, included, glabrous; stigma bilobed, lobes $0.1-0.2 \mathrm{~mm}$ long, papillate; nectary disc bipartite. Capsules broadly depressed obovoid, $2-3 \times 3.8-5 \mathrm{~mm}$, well-developed beak, crowned with the persistent calyx lobes, glabrous, dehiscence loculicidal. Seeds 1 per locule, ovate in outline, ventral groove present, $1.8-2 \times 1.3-1.5 \mathrm{~mm}$, black; seed coat surface reticulate; endosperm ruminate. 


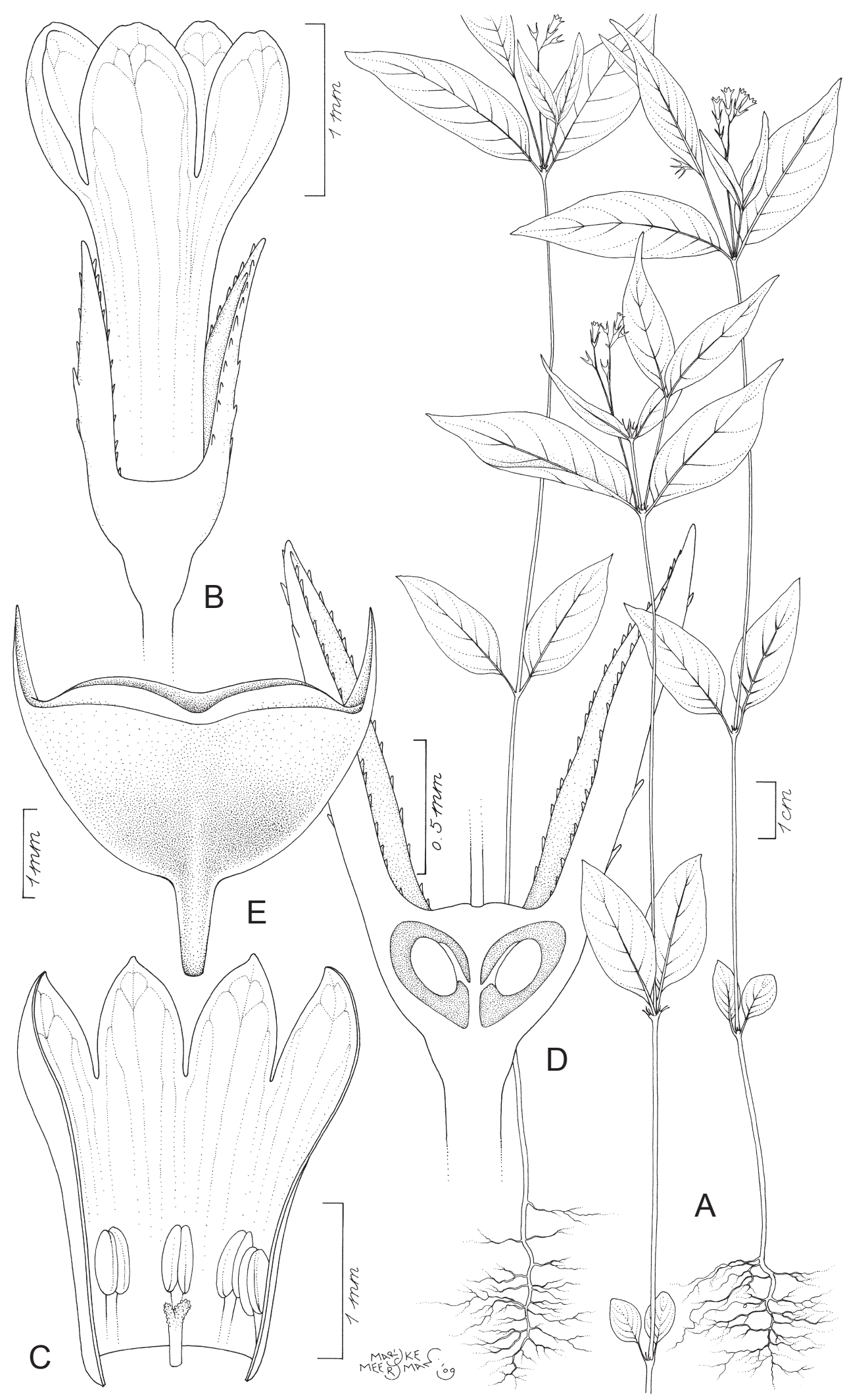

Fig. 8. Astiella delicatula Jovet. A. Habit. B. Isostylous flower. C. Open isostylous flower. D. Ovary dissected to show placentation. E. Capsule. Drawn by Marijke Meersman. All from De Block et al. 2173 (BR). 


\section{Distribution}

W Madagascar: Mahajanga province, Boeny region, Ambato Boeni district; Toliara province, AtsimoAndrefana region, Sakaraha district; Toliara province, Menabe region, Morondava district.

\section{Habitat}

Western dry forest; white sand or calcareous substrate; at 950-1000 m elevation.

\section{Conservation status}

The species is known from three localities, representing three different locations. The extent of occurrence equals $20,589.658 \mathrm{~km}^{2}$; the area of occupancy equals $12 \mathrm{~km}^{2}$. Two collections were made within the boundaries of a protected area. The main threat for the species is the deterioration of its habitat caused by the high human pressure in the area, which has also been observed within the protected areas. A decline in the extent of occurrence, area of occupancy, and area, extent, and/or quality of habitat is projected. The species is therefore considered endangered: EN B2ab(i,ii,iii).

Astiella desseinii Groeninckx sp. nov. http://www.ipni.org/urn:1sid:ipni.org:names:77161720-1

Figs 2F, 4D, 5E-F, 9

\section{Diagnosis}

Astiella desseinii sp. nov. resembles A. latifolia sp. nov. in having sessile flowers, elongated placentas, ovoid capsules, identical seed and pollen morphology, but differs in the erect habit (vs creeping), the linear leaves with secondary veins invisible (vs ovate to broadly ovate leaves with prominent secondary veins), and the cylindrical corolla tubes with the stamens exserted beyond the corolla throat in brevistylous flowers (vs funnel-shaped corolla tubes with the stamens always included).

\section{Etymology}

The species is named in honour of Dr. Steven Dessein, who was the first to observe and collect Astiella desseinii.

\section{Type}

MADAGASCAR: Toliara province, Menabe region, Morondava district, RN 35, at Antsehase bridge/ river, on elevated sandy bank near river, without herb or shrub vegetation, 197 m, 23 Jan. 2007, De Block et al. 2247 (holo-: BR; iso-: MO, P, TAN).

\section{Description}

Herb, up to $25 \mathrm{~cm}$ tall; stems quadrangular in cross section, glabrous or beset with minute trichomes with characteristic rounded apex towards the nodes, reddish green. Stipule base $0.4-0.8 \mathrm{~mm}$ long, covered with short trichomes with characteristic rounded apex; fimbriae often absent, sometimes 2 clearly visible and then $0.5-0.7 \mathrm{~mm}$ long, colleter-tipped. Leaves sessile, anisophyllous; blades linear, large leaves 6-22 $\times$ $0.7-1.5 \mathrm{~mm}$, small leaves $3.2-12 \times 0.6-1.2 \mathrm{~mm}$, beset with short trichomes with characteristic rounded apex above, glabrous below, yellow-green; base attenuate; apex acute; margin revolute when dry, beset with short trichomes with characteristic rounded apex; midvein prominent, purplish or reddish brown below; secondary veins invisible; intersecondaries invisible. Inflorescences pseudo-axillary, 1-2-flowered; peduncle absent. Flowers sessile, heterostylous. Calyx green; tube reduced; lobes 4, narrowly ovate to ovate with acute apex, $0.9-1.2 \times 0.3-0.5 \mathrm{~mm}$, glabrous or with a few trichomes, margin beset with short trichomes with characteristic rounded apex. Corolla yellow-green before anthesis, creamy white after; tube cylindrical, widened at the apex, $4-11 \mathrm{~mm}$ long, $0.7-1.2 \mathrm{~mm}$ wide at the throat, $0.4-0.6 \mathrm{~mm}$ wide at the base, glabrous; lobes 4 , broadly ovate, $1.2-1.7 \times 0.9-1.2 \mathrm{~mm}$, papillose outside, densely 


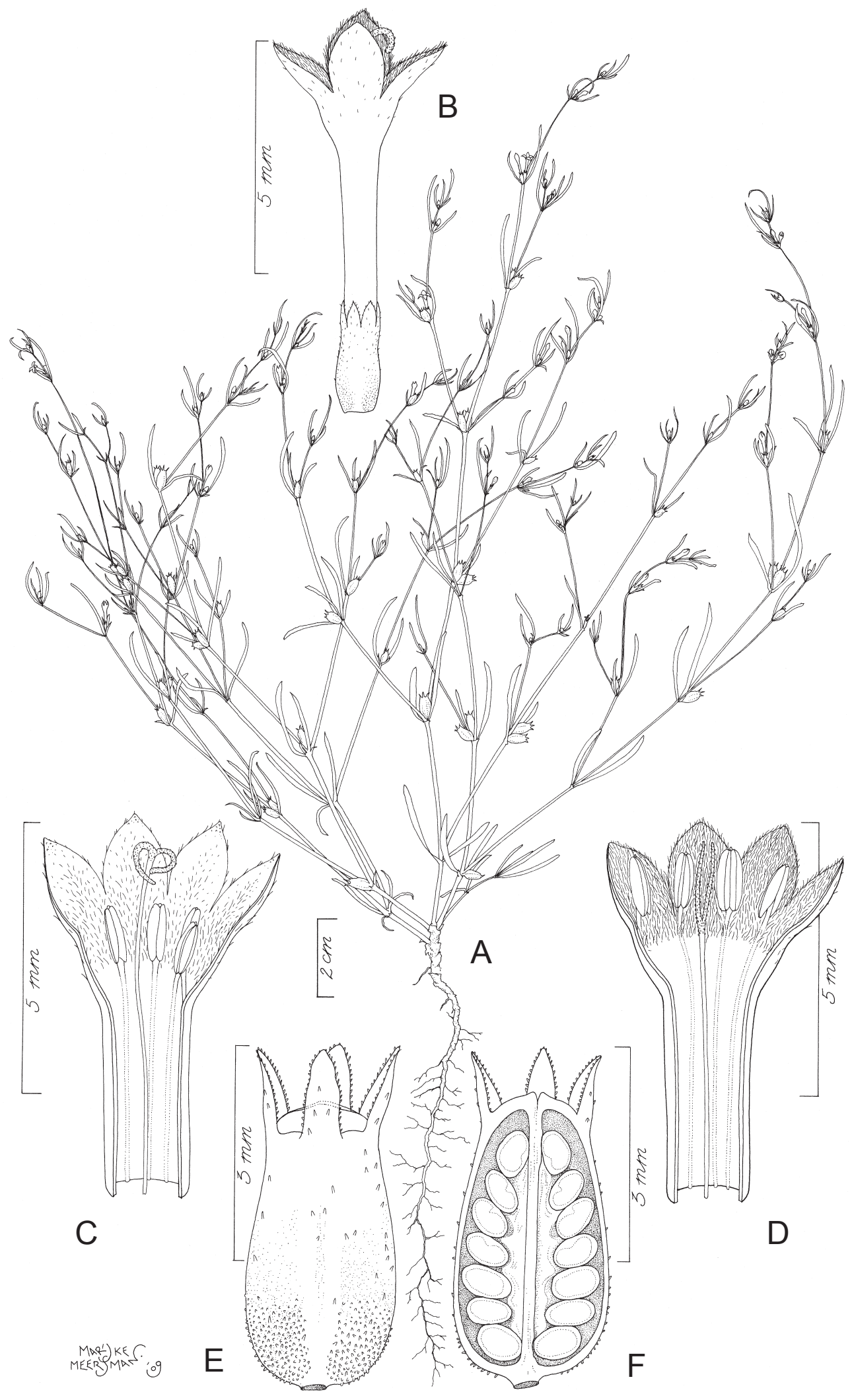

Fig. 9. Astiella desseinii Groeninckx sp. nov. A. Habit. B. Longistylous flower. C. Open longistylous flower. D. Open brevistylous flower. E. Capsule. F. Capsule dissected to show placentation. Drawn by Marijke Meersman. All from De Block et al. 2247 (BR). 
pubescent inside. Stamens inserted near the base of the corolla lobes and exserted for $0.8-1.2 \mathrm{~mm}$ beyond the corolla throat in brevistylous flowers, inserted in the lower half of the corolla tube and included in longistylous flowers. Anthers ellipsoid, 1-1.2 mm long; filaments dorsifixed, ca $0.5 \mathrm{~mm}$ long. Pollen tricolporate, prolate spheroidal to subprolate spheroidal; E $26.5 \mu \mathrm{m}$ in brevistylous flowers, $19-24 \mu \mathrm{m}$ in longistylous flowers; P $27 \mu \mathrm{m}$ in brevistylous flowers, $24-26 \mu \mathrm{m}$ in longistylous flowers; ectocolpi long; endocolpi long; tectum bireticulate; suprareticulum microreticulate to reticulate, mostly ornate, smooth or with granules; infrareticulum microreticulate with granules. Ovary 2-locular, ovoid, $1.2-1.5 \times 0.8-1 \mathrm{~mm}$, glabrous for the most part, covered with short trichomes with characteristic rounded apex towards the base; placenta fused with the septum, elongated, bearing 6-7 ovules per locule embedded in the placental tissue. Style $5 \mathrm{~mm}$ long and exserted for $0.2-1.3 \mathrm{~mm}$ beyond the corolla throat in brevistylous flowers, $4.8-6.5 \mathrm{~mm}$ long and exserted for $1.3-1.8 \mathrm{~mm}$ beyond the corolla throat in longistylous flowers, glabrous; stigma bilobed, lobes $0.5 \mathrm{~mm}$ long in longistylous flowers, $1-1.2 \mathrm{~mm}$ long in brevistylous flowers, papillate, white. Capsules ovoid, 3.4-3.8 $\times 1.8-2.3 \mathrm{~mm}$, crowned with the persistent calyx lobes, glabrous for the most part, covered with short trichomes with characteristic rounded apex towards the base, green becoming reddish brown, dehiscence loculicidal. Seeds 6-7 per locule, elliptic in outline, ventral groove absent, $5 \times 0.7-0.8 \times 5 \mathrm{~mm}$, black; seed coat surface reticulate, testa cells with undulating radial walls, microsculpturing granulate.

\section{Distribution}

W Madagascar: Toliara province, Menabe region, Morondava district.

\section{Habitat}

Plateau grassland-wooded grassland mosaic; elevated sandy bank near river; laterite; at $197 \mathrm{~m}$ elevation.

\section{Conservation status}

The species is only known from its type locality. The species was collected from an elevated sandy bank. No threat could be identified, but as very little is known about the ecology of the species, we categorise the species as data deficient (DD).

\section{Astiella homolleae Groeninckx sp. nov. http://www.ipni.org/urn:lsid:ipni.org:names:77161721-1}

Figs $2 \mathrm{G}, 5 \mathrm{~J}-\mathrm{K}, 10,11 \mathrm{~A}$

\section{Diagnosis}

Astiella homolleae sp. nov. resembles A. perrieri sp. nov. in having reduced corolla tubes with the stamens always exserted beyond the corolla throat, but differs in having a perennial, erect habit (vs annual and creeping), stipules with many, long fimbriae (4-8 vs 2-4 fimbriae and $1-4 \mathrm{~mm}$ vs $0.8-2.7 \mathrm{~mm}$ long), a corolla tube papillate on the inside with trichomes towards the base (vs glabrous), and seeds triangular in outline with a verruculate microsculpturing (vs seeds elliptic in outline with granulate microsculpturing).

\section{Etymology}

The species is named in honour of the French botanist Anne-Marie Homolle, who annotated many of the Madagascan Spermacoceae specimens in the herbarium of Paris.

\section{Type}

MADAGASCAR: Antsiranana province, Sava region, Antalaha district, Partie occidentale du massif de Marojejy (nord-est) de la vallée de l'Ambatoharanana au bassin supérieur de l'Antsahaberoka, forêt ombrophile sur argile latéritique de gneiss et granite, 1300 m, 9 Nov.-2 Dec. 1959, Humbert \& Saboureau 31739 (holo-: P; iso-: BR). 


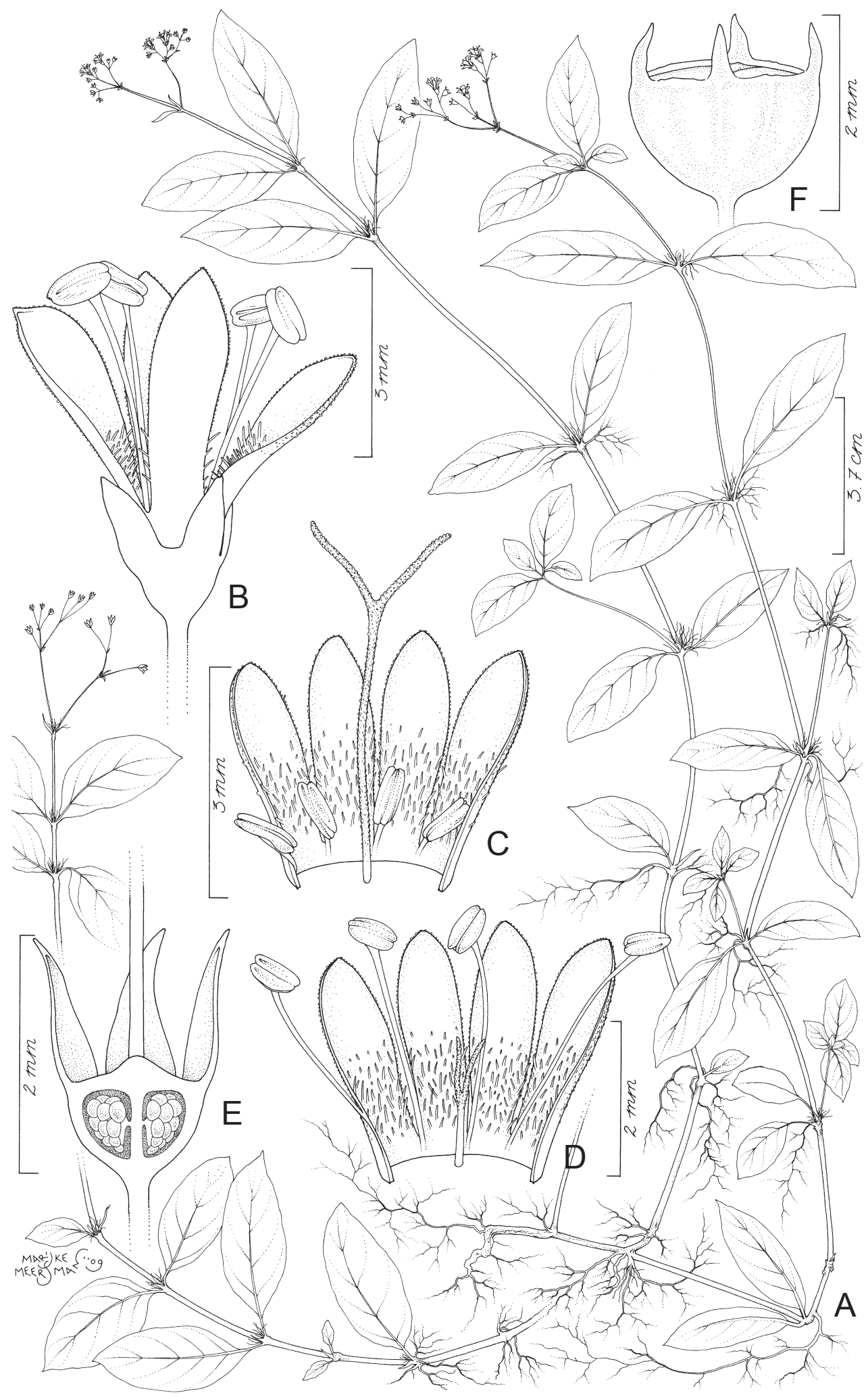

Fig. 10. Astiella homolleae Groeninckx sp. nov. A. Habit. B. Brevistylous flower. C. Open longistylous flower. D. Open brevistylous flower. E. Ovary dissected to show placentation. F. Capsule. Drawn by Marijke Meersman. A from Perrier de la Bâthie 17438 (P); B-E from Humbert \& Saboureau 31739 (BR); F from Cheek \& Dominic 1325 (K). 


\section{Additional material examined}

MADAGASCAR: Antsiranana province, Sava region, Andapa district, Pentes occidentales du massif de Marojejy (nord-est), bassin de la Lokoho, à l'est d'Ambalamanasy II, forêt ombrophile sur latérite de gneiss, 450-800 m, 28 Nov.-6 Dec. 1948, Humbert \& Capuron 22130 (BR, P). Masoala Peninsula, S of Ambanizana, Andranobe, Piste A, primary wet evergreen forest, 200 m, 18 Feb. 1999, Hoffman et al. $61(\mathrm{~K})$; Masoala Peninsula, trail leading south from Ambanizana along coast 1-2 km S of Ambanizana, 0-20 m, 26 Sep. 1989, Schatz 2746 (MO, P, TAN). Sambava district, Antsiranana, sous-préfecture d'Andapa, commune rurale de Doany, fokontany de Betsomanga, versant nord-ouest du Marojejy, camp I, $0.5 \mathrm{~km}$ à l'ENE du camp I, relevé LG 18, forêt dense humide sempervivente, versant, $860 \mathrm{~m}, 19$ Oct. 2001, Gautier, Ravelonarivo \& Andriamparany 3873 (K); Vallée inférieure de l'Androranga, affluent de la Bemarivo (nord-est) aux environs d'Antongodria [Antongondriha], massif du Betsomanga, $1200 \mathrm{~m}$, 17-20 Nov. 1950, Humbert \& Capuron 24314 (P); Vallée inférieure de l'Androranga, affluent de la Bemarivo (nord-est) aux environs d'Antongodria [Antongondriha], massif du Betsomanga, 13001350 m, 17-20 Nov. 1950, Humbert \& Capuron 24369 (P). Toamasina province, Analanjirofo region, Mananara district, Rivière Anove, bois, côte est, 200 m, Sep. 1912, Perrier de la Bâthie 3743 (P). Maroantsetra district, Maroantsetra, Antalavia, ca $50 \mathrm{~m}$ inland from the sea, lowland evergreen forest,
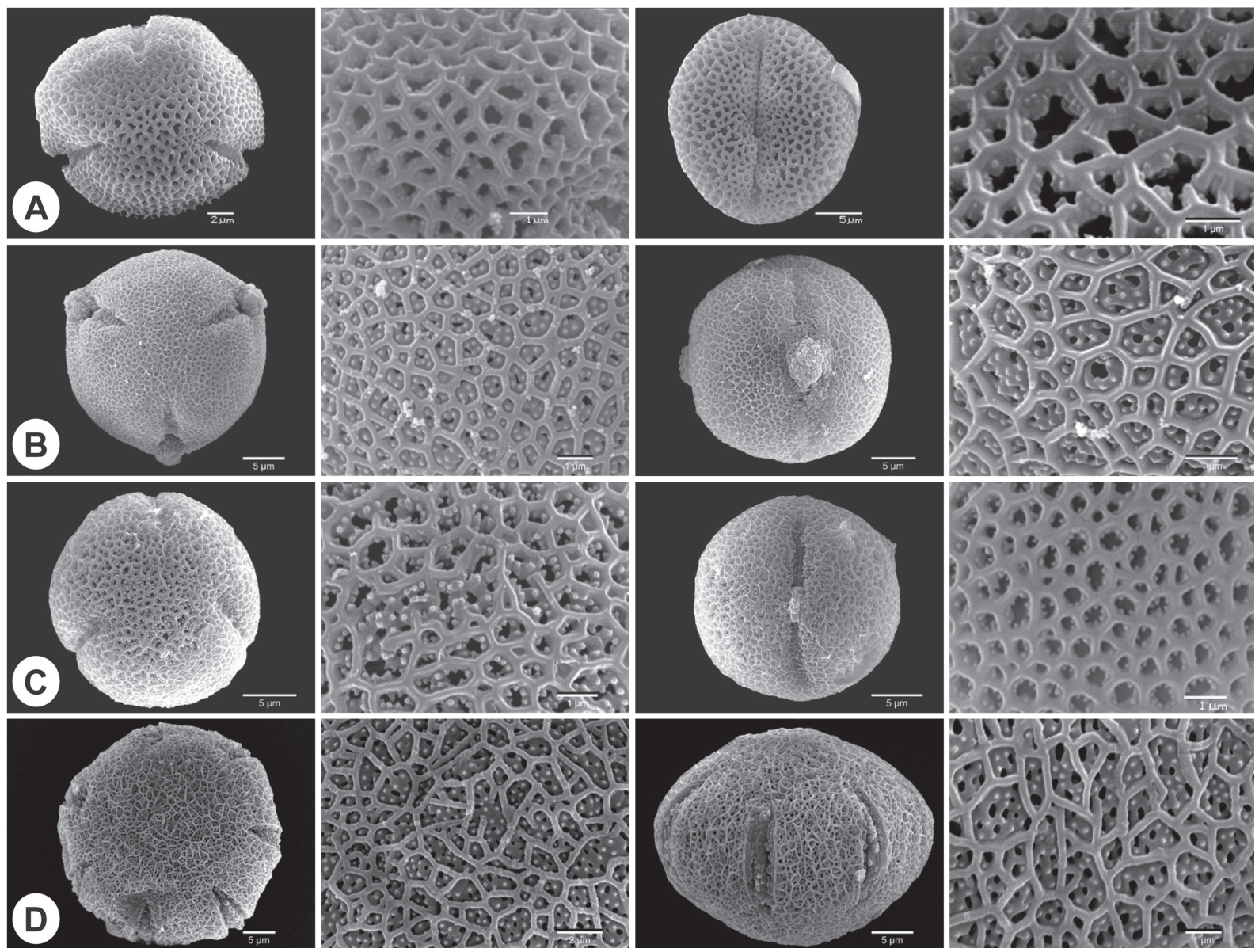

Fig. 11. Scanning electron microscopy micrographs of pollen in polar view (PV), the apocolpium (AC), pollen in equatorial view (EV) and the mesocolpium (ME). A. Astiella homolleae Groeninckx sp. nov. B. A. latifolia Groeninckx sp. nov. C. A. perrieri Groeninckx sp. nov. D. A. tsaratanensis Groeninckx sp. nov. Scale bars for A: $\mathrm{PV}=2 \mu \mathrm{m}, \mathrm{AC}, \mathrm{ME}=1 \mu \mathrm{m}, \mathrm{EV}=5 \mu \mathrm{m}$; for $\mathrm{B}$ and $\mathrm{C}$ : PV, $\mathrm{EV}=5 \mu \mathrm{m}, \mathrm{AC}$, $\mathrm{ME}=1 \mu \mathrm{m}$; for $\mathrm{D}: \mathrm{PV}, \mathrm{EV}=5 \mu \mathrm{m}, \mathrm{AC}=2 \mu \mathrm{m}, \mathrm{ME}=1 \mu \mathrm{m}$. 
many Guttiferae, amongst litter on forest floor, steep slope, 150 m, 20 Feb. 1988, Cheek \& Dominic 1325 (K, MO, TAN); Côte est, environs de la baie d'Antongil, bois, 400 m, Nov. 1912, Perrier de la Bâthie 3750 (P). Sainte Marie district, Sainte Marie, Dec. 1849, Boivin s.n. (P). Atsinanana region, Toamasina II district, Betampona près d'Ambodiriana, W de Tamatave, forêt orientale, Dec. 1925, Perrier de la Bâthie 17438 (P). Fianarontsoa province, Vatovavy-Fitovinany region, Mananjary district, Kianjavato, route du Mananjary, bords de chemins, Jan. 1964, Bosser 18878 (P, TAN). Bord de la Lokoho, 1000 m, 2 Jan. 1949, Cours 3437 (BR, P). Locality unknown, s. loc., s.d., Humblot 453 (P).

\section{Description}

Perennial herb, up to $60 \mathrm{~cm}$ tall, rooting at the basal nodes; stems quadrangular in cross section, glabrous or rarely with a few scattered trichomes. Stipule base 1-2 mm long, with a few scattered trichomes; fimbriae 4-8, 1-4 mm long, colleter-tipped. Leaves petiolate; petioles 2-5.5 $\mathrm{mm}$ long, glabrous; blades elliptic or ovate, rarely narrowly elliptic or narrowly ovate, $7-32.5(-92) \times 4.5-14.5(-30) \mathrm{mm}$, glabrous, darker green above, very pale green below; base attenuate; apex acuminate or acute, rarely obtuse; margin glabrous; midvein prominent; secondary veins $3-6$ on each side of the midvein, prominent or invisible; intersecondaries invisible. Inflorescences terminal, compound dichasia, multi-flowered; peduncle $0-40 \mathrm{~mm}$ long, glabrous or rarely scabrate. Pedicels $0.5-5 \mathrm{~mm}$ long, glabrous or rarely scabrate. Flowers heterostylous. Calyx green; tube reduced; lobes 4, triangular or narrowly triangular, $0.9-1.2 \times 0.3-0.4 \mathrm{~mm}$, glabrous, colleters in between. Corolla white; tube reduced, $0.2-0.6 \mathrm{~mm}$ long, glabrous; lobes 4 , narrowly elliptic to elliptic, $2-3 \times 0.6-1.2 \mathrm{~mm}$, glabrous or with a few trichomes outside, papillate with trichomes towards the base inside. Stamens inserted near the base of the corolla lobes, exserted for $2.5-3 \mathrm{~mm}$ beyond the corolla throat in brevistylous flowers, exserted $0.7-1 \mathrm{~mm}$ beyond the corolla throat in longistylous flowers. Anthers ellipsoid, $0.4-0.6 \mathrm{~mm}$ long in brevistylous flowers, $0.7-0.8 \mathrm{~mm}$ long in longistylous flowers; filaments dorsifixed, $2.3-3 \mathrm{~mm}$ long in brevistylous flowers, $0.5-0.6 \mathrm{~mm}$ long in longistylous flowers. Pollen tricolporate, oblate spheroidal to prolate spheroidal; E 20-16 $\mu \mathrm{m}$; P 15-22 $\mu \mathrm{m}$; ectocolpi long; endocolpi long; tectum bireticulate; suprareticulum microreticulate to reticulate; infrareticulum present as granules in the lumina of the suprareticulum. Ovary 2-locular, broadly depressed obovoid, $0.6-0.7 \times 0.8-1 \mathrm{~mm}$, glabrous; placenta attached near the middle of the septum, stalked, globose, bearing numerous ovules per locule. Style ca $1.2 \mathrm{~mm}$ long and included in brevistylous flowers, $3.5-4.5 \mathrm{~mm}$ long and exserted for $2.6-4 \mathrm{~mm}$ beyond the corolla throat in longistylous flowers, papillate or hirtellous; stigma bilobed, lobes ca $0.4 \mathrm{~mm}$ long in brevistylous flowers, $0.8-1.3 \mathrm{~mm}$ long in longistylous flowers, papillate or hirtellous. Capsules broadly depressed obovoid, $1-2 \times 1.8-2.5 \mathrm{~mm}$, crowned with the persistent calyx lobes, glabrous, dehiscence loculicidal. Seeds numerous per locule, triangular in outline, ventral groove absent, $0.4-0.5 \times 0.2-0.4 \mathrm{~mm}$, black; seed coat surface reticulate, microsculpturing verruculate.

\section{Distribution}

NE to E Madagascar: Antsiranana province, Sava region, Andapa, Antalaha, and Sambava districts; Toamasina province, Analanjirofo region, Mananara, Maroantsetra, and Sainte Marie districts; Toamasina province, Atsinanana region, Toamasina II district; Fianarantsoa province, Vatovavy-Fitovinany region, Mananjary district.

\section{Habitat}

Humid forest; laterite and granite substrate; at 0-1300 m elevation.

\section{Conservation status}

The species is known from 15 collections, of which two without locality. The number of locations is eight. The extent of occurrence is more than $20,000 \mathrm{~km}^{2}$; the area of occupancy equals $48 \mathrm{~km}^{2}$. Throughout its distribution range there is a high human pressure on the habitat of this species, even 

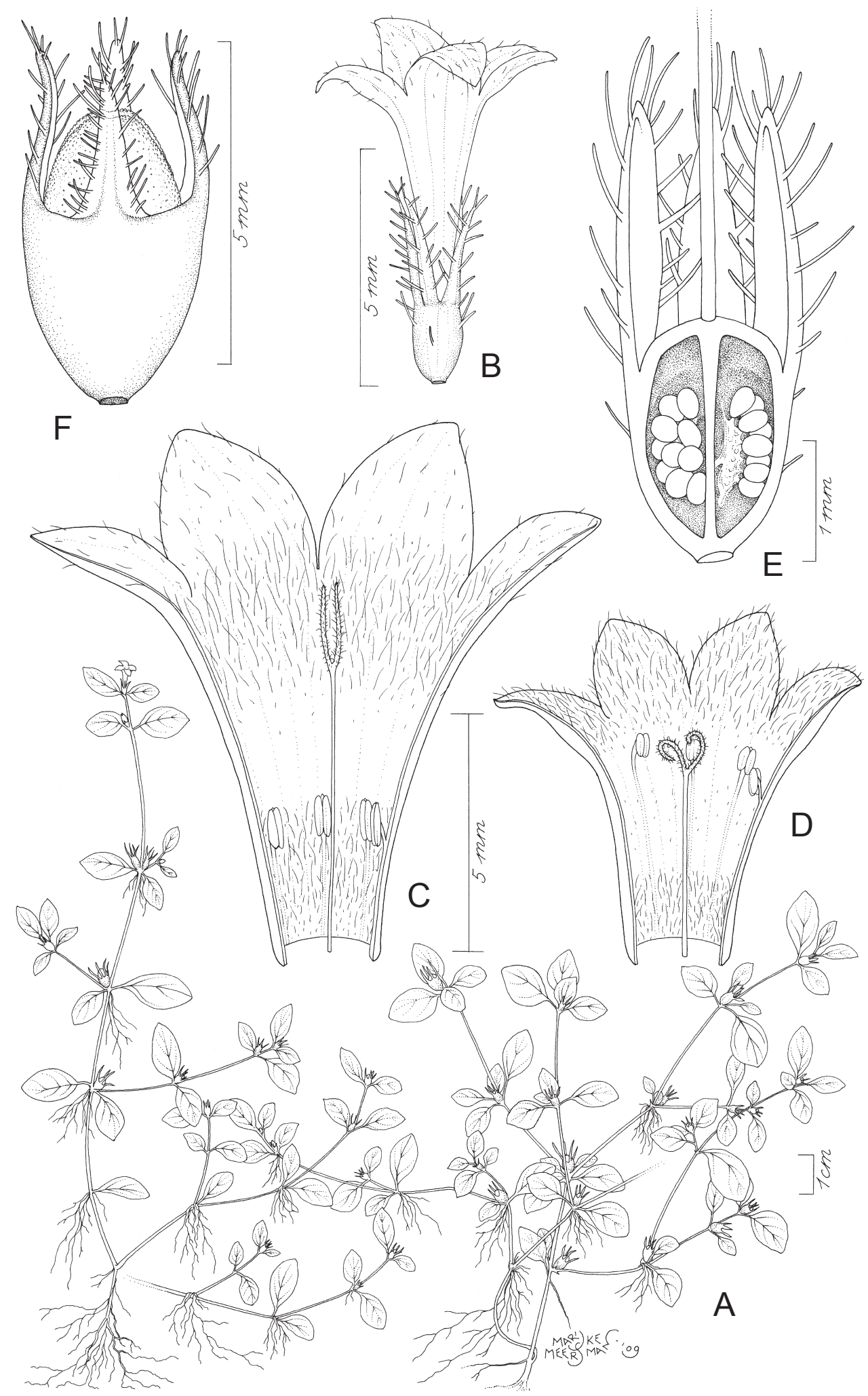

Fig. 12. Astiella latifolia Groeninckx sp. nov. A. Habit. B. Longistylous flower. C. Open longistylous flower. D. Open brevistylous flower. E. Ovary dissected to show placentation; some ovules removed from the right locule to show the shape of the placenta. F. Capsule. Drawn by Marijke Meersman. A, D-F from De Block et al. 2255 (BR); B-C from Baron 5214 (P). 
within the protected areas. A continuing decline of the extent of occurrence, area of occupancy, and area, extent, and/or quality of habitat is projected. The species is therefore classified as vulnerable: VU B2ab(i,ii,iii).

Astiella latifolia Groeninckx sp. nov.

http://www.ipni.org/urn:1sid:ipni.org:names:77161722-1

Figs $2 \mathrm{H}, 5 \mathrm{~L}-\mathrm{M}, 11 \mathrm{~B}, 12$

\section{Diagnosis}

Astiella latifolia sp. nov. resembles A. desseinii sp. nov. in having sessile flowers, elongated placentas, ovoid capsules, identical seed and pollen morphology, but differs in the creeping habit (vs erect), the ovate to broadly ovate leaves with prominent secondary veins (vs linear leaves with secondary veins invisible), and the funnel-shaped corolla tubes with the stamens always included (vs cylindrical corolla tubes with the stamens exserted beyond the corolla throat in brevistylous flowers).

\section{Etymology}

The species name is derived from the Latin adjective 'latus' (= broad, wide) and noun 'folium' (= leaf), referring to the ovate or broadly ovate leaves. It also refers to the illegitimate name Oldenlandia latifolia Baker.

\section{Type}

MADAGASCAR: Fianarantsoa, PK 365 on RN 2 from Antananarivo to Fianarantsoa, dense low grassy vegetation alongside road and Eucalyptus forest, 1213 m, 29 Jan. 2007, De Block et al. 2255 (holo-: BR; iso-: $\mathrm{BR}, \mathrm{MO}, \mathrm{P}, \mathrm{TAN})$.

\section{Additional material examined}

MADAGASCAR: Antananarivo province, Vakinankaratra region, Antsirabe I district, Antsirabe, vieux murs, 1500 m, Apr. 1919, Perrier de la Bâthie 12577 (P). Betafo district, Environs de Tritriva, près Antsirabe, cratères basaltiques, endroits humides, $1700 \mathrm{~m}$, May 1912, Perrier de la Bâthie 3936 (P). Diana region, Ambanja district, Marovato, Ambanja, 13 Mar. 1954, Sajy 6309-RN(P, TAN). Fianarantsoa province, Amoron'i Mania region, Ambatofinandrahana district, Environs d'Ambatofinandrahana, sables quartzeux, 1600-1800 m, 23 Feb. 1938, Decary 19278 (P). Haute Matsiatra region, Ambalavao district, RN 5, Sendrisoa, Ambalavao, 19 Mar. 1952, [Razafindzakolo] 3984-RN (P). Ambohimahasoa district, Süd-Betsiléo, Wald von Ankafina, Mar. 1881, Hildebrandt 3941 (K, P). Fianarantsoa district, Fianarantsoa, rocailles, Apr. 1912, Perrier de la Bâthie 3584 (P). Horombe region, Ivohibe district, Andringitra, in manioc field, 1542 m, 28 Jan. 2006, De Block, Tosh \& Rakotonasolo 1920 (BR, MO, P, TAN). Mahajanga province, Boeny region, Ambato Boeni district, road from Ankarafantsika to AmbatoBoeni, ca $5 \mathrm{~km}$ after turn-off to Ambato-Boeni, close to Tsararivotra, hill on left side of the road when coming from Ankarafantsika, 88 m, 21 Mar. 2010, De Block, Groeninckx \& Rakotonasolo 2361 (BR, K, MO, P, TAN); Ankarafantsika, Jardin Botanique B, 144 m, 21 Mar. 2010, De Block, Groeninckx \& Rakotonasolo 2364 (BR, K, TAN); Anjiafitatra, près de Mont Tsitondroina (Boeny), sables ombragées, Mar. 1901, Perrier de la Bâthie 1254 (P); Ankarafantsika, sables très sec, Jan. 1902, Perrier de la Bâthie 3686 (P). Mahajanga I district, Ambodiroka, Betsiboka, Jan. 1902, Perrier de la Bâthie 4035 (P). Marovoay district, Ampijoroa, Jardin Botanique, section A, on sandy path in forest, temporarily humid, 10 Feb. 1999, De Block, Luckow \& Rakotonasolo 780 (BR, MO, TAN). Sofia region, Boriziny district, edge of RN 6, ca $17 \mathrm{~km} \mathrm{~N}$ of Port Bergé, left side of the road coming from Port Bergé, seasonally dry semi-deciduous forest, on white sand, 17 Mar. 2010, Groeninckx, De Block \& Rakotonasolo 261 (BR, K, MO, P, TAN); edge of RN 6, ca $17 \mathrm{~km} \mathrm{~N}$ of Port Bergé, left side of the road coming from Port Bergé, seasonally dry semi-deciduous forest, on white sand, 17 Mar. 2010, Groeninckx, De Block \& 
Rakotonasolo 262, 267 (BR, K, MO, TAN). Toliara province, Androy region, Ambovombe district, $43 \mathrm{~km}$ from Ambovombe on road from A1 to Betroka, grass along road, 187 m, 8 Feb. 2007, De Block et al. 2334 (BR, TAN). Anosy region, Taolanaro district, Fort-Dauphin, Scott Elliot 3059 (K, P). Locality unknown, s. loc., s.d., Baron 307 (K); s. loc., s.d., Baron 5214 (P); s. loc., s.d., Blackburn s.n. (K); s. loc., s.d., Boivin 115 (P).

\section{Description}

Annual herb, creeping, less than $10 \mathrm{~cm}$ tall, rooting at the nodes; stems quadrangular in cross section, only sparsely branching, with short (ca $0.2 \mathrm{~mm}$ ) and longer $(\mathrm{ca} 0.7 \mathrm{~mm}$ ) white trichomes on the adaxial side, glabrous or with short white trichomes on the abaxial side, light brown, purplish brown or reddish brown. Stipule base 1-1.5 mm long, beset with a few trichomes (up to $1 \mathrm{~mm}$ long); fimbriae 2-4, $0.8-2.7 \mathrm{~mm}$ long, beset with trichomes (up to $1 \mathrm{~mm}$ long), colleter-tipped. Leaves petiolate, rarely sessile, anisophyllous; petioles $0.5-6 \mathrm{~mm}$ long; blades elliptic, ovate or broadly ovate, large leaves $5-20(-30) \times 4-12 \mathrm{~mm}$, small leaves $4-9.5 \times 3-8.8 \mathrm{~mm}$, glabrous or sparsely covered with short (ca $0.6 \mathrm{~mm}$ ) appressed trichomes above particularly at the base (especially on younger leaves), glabrous below except for midvein and secondary veins that are covered with very short (ca $0.2 \mathrm{~mm}$ ) erect trichomes, darker green above, paler green below; base attenuate; apex acute; margin scabrate towards the apex, ciliate at the base; midvein prominent below; secondary veins $3-4$ on each side of the midvein, somewhat prominent below; intersecondaries invisible. Inflorescences terminal 3- to several-flowered and pseudo-axillary 1- or 2-flowered; peduncle absent. Flowers sessile, heterostylous. Calyx green to purplish; tube reduced; lobes 4 , narrowly triangular, $1.5-2.5 \times 0.2-0.5 \mathrm{~mm}$, margin ciliate with trichomes up to $1 \mathrm{~mm}$ long. Corolla white, pale pink or pale purple; tube funnel-shaped, $3.5-5.4 \mathrm{~mm}$ long, 2-2.8 mm wide at the throat and $0.5-1.1 \mathrm{~mm}$ wide at the base in brevistylous flowers, $6.8-8.5 \mathrm{~mm}$ long, 3.5-4.8 $\mathrm{mm}$ wide at the throat and $0.8-1.2 \mathrm{~mm}$ wide at the base in longistylous flowers, glabrous or with a few trichomes outside, covered with long spreading trichomes (up to $1 \mathrm{~mm}$ long) inside at the base and sometimes at the throat; lobes 4, ovate to broadly ovate, $1.7-2.5 \times 1.5-2 \mathrm{~mm}$ in brevistylous flowers, $3.2-3.8 \times 2.8-3.5 \mathrm{~mm}$ in longistylous flowers, glabrous or covered with a few trichomes outside, sparsely covered with long spreading trichomes (up to $1 \mathrm{~mm}$ long) inside. Stamens inserted at $3.5-4 \mathrm{~mm}$ height in the corolla tube in brevistylous flowers, inserted at $1.5-3 \mathrm{~mm}$ height in the corolla tube in longistylous flowers, always included. Anthers broadly obovoid, 0.4-0.6 mm long, white; filaments dorsifixed, $0.3-0.7 \mathrm{~mm}$ long. Pollen tricolporate, prolate spheroidal, sometimes oblate spheroidal or subprolate in brevistylous flowers, subprolate in longistylous flowers; E 22-26 $\mu \mathrm{m}$ in brevistylous flowers, $22-25 \mu \mathrm{m}$ in longistylous flowers; P $24-26 \mu \mathrm{m}$ in brevistylous flowers, $26-$ $28.5 \mu \mathrm{m}$ in longistylous flowers; ectocolpi long; endocolpi long; tectum bireticulate; suprareticulum microreticulate to reticulate; infrareticulum perforate to microreticulate with granules. Ovary 2-locular, ovoid, 1.3-1.4 × 1.2-1.3 mm, sparsely covered with trichomes; placenta attached near the middle of the septum, stalked, elongated, bearing 5-10 ovules per locule. Style 3.3-4.8 $\mathrm{mm}$ long in brevistylous flowers, $6-8 \mathrm{~mm}$ long in longistylous flowers, always included, glabrous, white; stigma bilobed, lobes $0.5-0.8 \mathrm{~mm}$ long in brevistylous flowers, $1.5-2 \mathrm{~mm}$ long in longistylous flowers, hirtellous. Capsules ovoid, 3-4.5 $\times 2-3.5 \mathrm{~mm}$, with beak $0.8-1.7 \mathrm{~mm}$ long, crowned with the persistent calyx lobes, glabrous or covered with a few trichomes, green with brown beak, dehiscence loculicidal. Seeds $5-10$ per locule, elliptic in outline, ventral groove absent, $0.6-0.8 \times 0.5-0.6 \times 0.4-0.6 \mathrm{~mm}$, black; seed coat surface reticulate, testa cells with undulating radial walls, microsculpturing granulate.

\section{Distribution}

NW to SE Madagascar: Antananarivo province, Vakinankaratra region, Antsirabe I and Betafo districts; Antsiranana province, Diana region, Ambanja district; Fianarantsoa province, Amoron'i Mania region, Ambatofinandrahana district; Fianarantsoa province, Haute Matsiatra region, Ambalavao, Ambohimahasoa, and Fianarantsoa districts; Fianarantsoa province, Horombe region, Ivohibe district; 
Mahajanga province, Boeny region, Ambato Boeni, Mahajanga I, and Marovoay districts; Mahajanga province, Sofia region, Boriziny district; Toliara province, Androy region, Ambovombe district; Toliara province, Anosy region, Taolanaro district.

\section{Habitat}

Western dry forest and humid forest; often disturbed vegetations (i.e. degraded dry forest, grass along roads, sandy paths in forests, manioc fields and walls); sand; at 88-1800 m elevation.

\section{Vernacular name}

Masiramboalavo.

\section{Conservation status}

The species is known from 23 collections, of which four without locality. The extent of occurrence equals $195,897.347 \mathrm{~km}^{2}$ and the area of occupancy equals $72 \mathrm{~km}^{2}$. Astiella latifolia $\mathrm{sp}$. nov. has frequently been collected from disturbed areas. No real threats could be identified and the species does therefore not qualify for an IUCN red list threatened category (LC).

Astiella longifimbria Groeninckx sp. nov. http://www.ipni.org/urn:1sid:ipni.org:names:77161724-1

Figs 2I, 13

\section{Diagnosis}

Astiella longifimbria sp. nov. resembles A. homolleae sp. nov. in having long fimbriate stipules, but differs in having corolla lobes moderately covered with appressed trichomes (vs glabrous), and a welldeveloped corolla tube (vs reduced).

\section{Etymology}

The specific epithet refers to the long fringes of the stipules.

\section{Type}

MADAGASCAR: Mahajanga province, Sofia region, Bealanana district, Montagnes au nord de Mangindrano (haute Maevarano) jusqu'aux sommets d'Ambohimirahavavy (partage des eaux Mahavavy-Androranga: centre-nord), clairières naturelles en forêt ombrophile sur latérite de gneiss (berges) de la Bemafo affluent de l'Androranga, 1900 m, 19 Jan.-12 Feb. 1951, Humbert \& Capuron 25168 (holo-: P; iso-: BR, P).

\section{Description}

Herb, up to $15 \mathrm{~cm}$ tall, rooting at the basal nodes; young stems quadrangular in cross section, lanate, with reddish brown multicellular trichomes up to $1 \mathrm{~mm}$ long, older stems glabrous. Stipule base $0.8-1.5 \mathrm{~mm}$ long, moderately covered with reddish brown appressed trichomes; fimbriae 2-4, 4-6.5 mm long, beset with reddish brown trichomes. Leaves petiolate; petioles $3-11.5 \mathrm{~mm}$ long, lanate; blades ovate to elliptic, $12-50 \times 5.5-23 \mathrm{~mm}$, sparsely covered with appressed trichomes up to $0.5 \mathrm{~mm}$ long particularly on the midvein and in between the secondary veins above, sparsely covered with appressed trichomes up to $0.5 \mathrm{~mm}$ long particularly on the midvein and on the secondary veins below; base attenuate; apex acute or obtuse; margin revolute when dry, densely ciliolate; midvein prominent below; secondary veins 3-7 on each side of the midvein, prominent below; intersecondaries invisible. Inflorescences terminal, compound dichasia, several-flowered; peduncle 5-22.5 $\mathrm{mm}$ long, with indumentum similar to the stems. Pedicels $0.5-11 \mathrm{~mm}$ long, with indumentum similar to the stems. Flowers probably heterostylous (only flowers with anthers exserted and style included have been observed). Calyx green; 


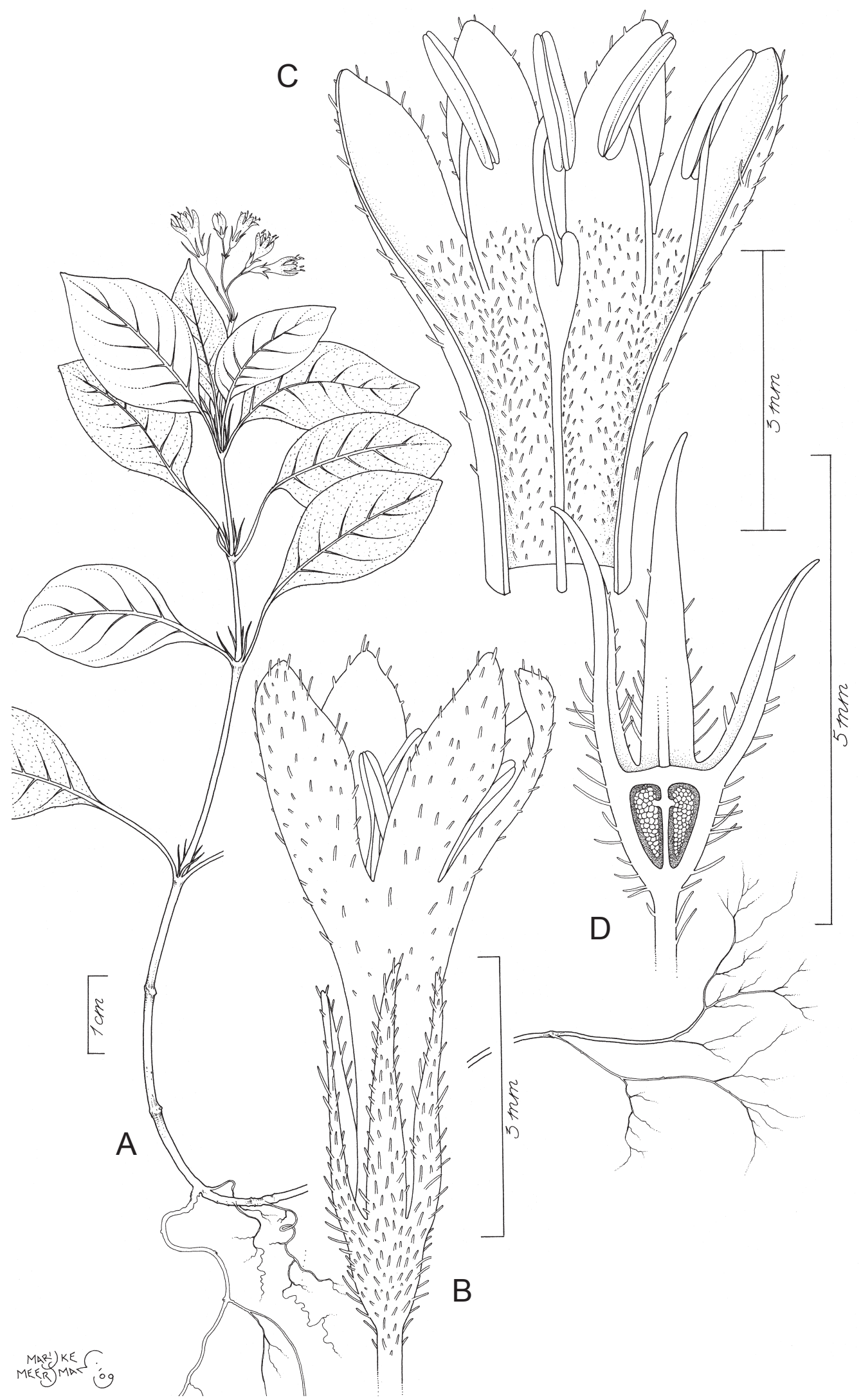

Fig. 13. Astiella longifimbria Groeninckx sp. nov. A. Habit. B. Flower. C. Open flower. D. Ovary dissected to show placentation. Drawn by Marijke Meersman. All from Humbert \& Capuron 25168 (P). 
tube reduced; lobes 4 , narrowly ovate, 3.5-4.2 $\times 0.3-0.4 \mathrm{~mm}$, densely pubescent. Corolla white or pale blue; tube funnel-shaped, $2.5-4.5 \mathrm{~mm}$ long, $0.6-0.9 \mathrm{~mm}$ wide at the base, $1.7-2 \mathrm{~mm}$ wide at the apex, moderately covered with appressed trichomes outside, densely covered with spreading trichomes inside; lobes 4 , ovate, $2-4.5 \times 1.2-1.3 \mathrm{~mm}$, moderately covered with appressed trichomes outside, glabrous inside except for a ring of trichomes at the base. Stamens inserted near the base of the corolla lobes in presumed brevistylous flowers and exserted for $2.5-3 \mathrm{~mm}$ beyond the corolla throat. Anthers ellipsoid, 1.3-1.8 mm long; filaments dorsifixed, $1.5-2.3 \mathrm{~mm}$ long. Pollen unknown. Ovary 2-locular, broadly obpyramidal, $1-1.2 \times 1 \mathrm{~mm}$, densely covered with spreading trichomes up to $0.6 \mathrm{~mm}$ long; placenta attached above the middle of the septum, stalked, elongated, bearing numerous ovules per locule. Style ca $4 \mathrm{~mm}$ long and included in presumed brevistylous flowers; stigma bilobed, lobes ca $1.2 \mathrm{~mm}$ long, papillate. Capsules and seeds unknown.

\section{Distribution}

NW Madagascar: Mahajanga province, Sofia region, Bealanana district.

\section{Habitat}

Humid forest; laterite substrate; at 1900 m elevation.

\section{Conservation status}

Known from only one locality. Given its apparent rarity and following the recommendation of Callmander et al. (2005) to avoid the Data Deficient category, we consider the species as vulnerable (VU D2) based on its restricted area of occupancy (D2) and the high human pressure present in the entire area resulting in a general decline of suitable habitats (humid forest) for the species.

\section{Astiella perrieri Groeninckx sp. nov. http://www.ipni.org/urn:1sid:ipni.org:names:77161726-1}

Figs $2 \mathrm{~J}, 5 \mathrm{~N}-\mathrm{O}, 11 \mathrm{C}, 14$

\section{Diagnosis}

Astiella perrieri sp. nov. resembles A. homolleae sp. nov. in having a reduced corolla tube with the stamens always exserted beyond the corolla throat, but differs in having an annual habit (vs perennial), stipules with less and shorter fimbriae ( $2-4$ fimbriae vs $4-8$ and $0.8-2.7 \mathrm{~mm}$ vs $1-4 \mathrm{~mm}$ long), a glabrous corolla tube on the inside (vs papillate with trichomes towards the base), and seeds elliptic in outline with granulate microsculpturing (vs seeds triangular in outline with a verruculate microsculpturing).

\section{Etymology}

The specific epithet is dedicated to the French botanist H. Perrier de la Bâthie who specialized in the plants of Madagascar.

\section{Type}

MADAGASCAR: Fianarantsoa province, Horombe region, Ivohibe district, Andringitra, area around campement 1, humid forest, along forest trails and in open places, 28 Jan. 2006, De Block, Tosh \& Rakotonasolo 1927 (holo-: BR; iso-: BR, MO, P, TAN).

\section{Additional material examined}

MADAGASCAR: Antanarivo province, Analamanga region, Anjozorobe district, Ampilanonana, Ambohitsitakatra, 1300 m, 3 Apr. 1999, Rakotonasolo \& Ramaroson 89 a (BR, K); Ampilanonana, Ambohitsitakatra, on rock, 1300 m, 3 Apr. 1999, Rakotonasolo \& Ramaroson 90 (K, TAN). Antsiranana province, Melaky region, Besalampy district, Mares de dissolution latéritique, plateau de Marangaka 


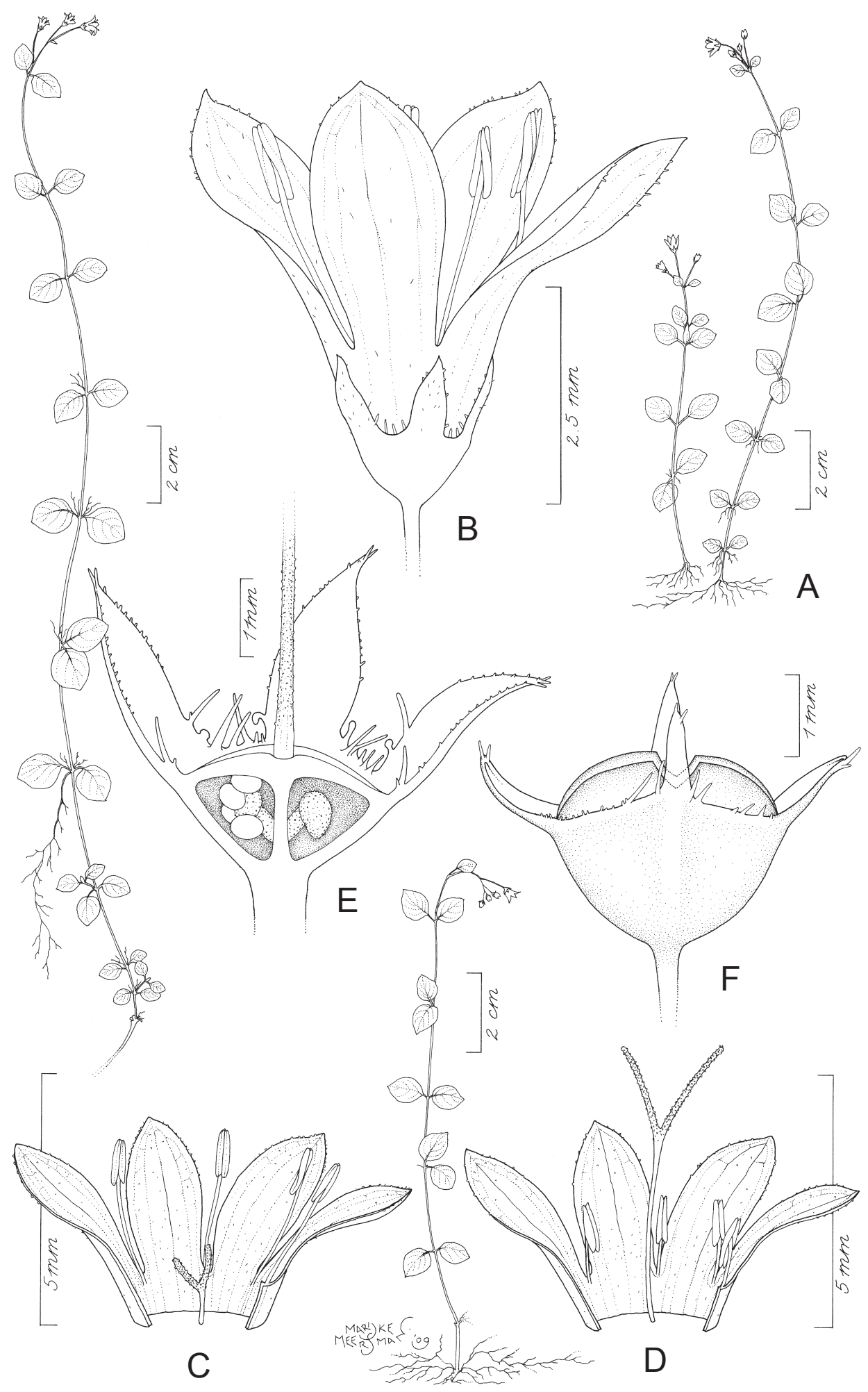

Fig. 14. Astiella perrieri Groeninckx sp. nov. A. Habit. B. Brevistylous flower. C. Open brevistylous flower. D. Open longistylous flower. E. Ovary dissected to show placentation; all ovules removed from the right locule to show the placenta. F. Capsule. Drawn by Marijke Meersman. A-C, E from De Block, Tosh \& Rakotonasolo 1927 (BR); D from Perrier de la Bâthie 3958 (P); F from Perrier de la Bâthie $14472(\mathrm{P})$. 
[Mrangaka], 1600 m, Dec. 1912, Perrier de la Bâthie 15163 (P). Fianarantsoa province, AtsimoAtsinanana region, Befotaka district, Pce. de Farafangana, bord des routes en forêt humide, 16 Aug. 1926, Decary 4431 (P). Horombe region, Ivohibe district, Massif d'Andringitra, forêt à sous bois herbacé, 1600 m, Feb. 1922, Perrier de la Bâthie 14472 (P). Mahajanga province, Sofia region, Bealanana district, Montagnes au nord de Mangindrano (haute Maevarano) jusqu'aux sommets d'Ambohimirahavavy (partage des eaux Mahavavy Androranga: centre nord), clairière maricageuse dans la forêt ombrophile sur latérite de gneiss, par petites plaques à la lisière, en prairie secondaire, $1900 \mathrm{~m}, 19 \mathrm{Jan} .-12 \mathrm{Feb}$. 1951, Humbert \& Capuron 24953 (BR, MO, P, TAN). Toamasina province, Alaotra-Mangoro region, Moramanga district, Beforona [Bé-fouram], s.d., Bojer s.n. (K, P). Anosibe An'Ala district, Terrain humide près d'un forêt, village d'Analamazava [Alamazaze], 1000 m, 13 May 1881, Lantz s.n. (P). Analanjirofo region, Maroantsetra district, Island of Nosy Mangabe, $5 \mathrm{~km} \mathrm{~S}$ of Maroantsetra in the Bay of Antongil, along north trail, in full shade, 10 m, 26 Apr. 1990, Carlson 179 (MO, TAN); Nosy Mangabe coastal path from $\mathrm{W}$ landing towards $\mathrm{N}$ end, bank above path, lowland evergreen rainforest, near Cyperus and Diospyros, on laterite, 10 m, 29 Feb. 1988, Cheek \& Schatz 1380 (K); Nosy Mangabe, a 520 ha island in the Bay of Antongil, $5 \mathrm{~km}$ from Maroantsetra, 0-330 m, 9 Jan. 1989, Schatz \& Miller 2514 (MO, P, TAN); Nosy Mangabe, a 520 ha island in the Bay of Antongil, $5 \mathrm{~km}$ from Maroantsetra, 0-330 m, 4 Dec. 1987, Schatz \& Villiers 1833 (K, MO, P, TAN). Locality unknown, Bois humides, rivière Simianona [Simiana], 200 m, Sep. 1912, Perrier de la Bâthie 3958 (P); Bois, rivière Mananara, 200 m, Oct. 1912, Perrier de la Bâthie 9741 (P).

\section{Description}

Annual herb, creeping, fertile stems $4-20 \mathrm{~cm}$ tall, with fine rooting system, rooting at the nodes; stems quadrangular in cross section, only sparsely branching, glabrous or puberulent, green to reddish green. Stipule base $0.5-1.5 \mathrm{~mm}$ long, glabrous or pubescent; fimbriae $2-4,0.8-2.7 \mathrm{~mm}$ long, colleter-tipped. Leaves petiolate or sessile; petioles $0.5-3.5 \mathrm{~mm}$ long, glabrous; blades broadly elliptic or broadly ovate, more rarely elliptic, $2.2-26.5 \times 1.8-14.5 \mathrm{~mm}$, sparsely to densely strigose above particularly towards the edges (but see remarks), glabrous to sparsely puberulent below particularly on the veins, darker green above, paler green below; base attenuate; apex acute; margin ciliolate; midvein prominent particularly below; secondary veins $2-5$ at each side of the midvein, prominent below; intersecondaries prominent. Inflorescences terminal or pseudo-axillary, single or compound dichasia, 3- to severalflowered, subtended by one leaf pair; peduncle absent or 5-40 $\mathrm{mm}$ long, glabrous; lower bracts leaf-like, upper bracts fimbriate. Pedicels $0.5-16 \mathrm{~mm}$ long, glabrous to sparsely puberulent. Flowers heterostylous. Calyx green; tube reduced; lobes 4, triangular to narrowly triangular, $1-1.5 \times 0.4-0.6 \mathrm{~mm}$, glabrous or beset with trichomes particularly at the sinuses, colleters in between. Corolla white, pale pink, pale blue or pale purple; tube reduced or cylindrical, $0.6-1.5 \mathrm{~mm}$ long (but see remarks), glabrous; lobes 4, elliptic, $1.2-2.7 \times 1.1-1.7 \mathrm{~mm}$, glabrous outside, papillate and sparsely beset with trichomes inside. Stamens inserted near the base of the corolla lobes, exserted for $1.5-2.2 \mathrm{~mm}$ beyond the corolla throat in brevistylous flowers, exserted for $0.5-1.5 \mathrm{~mm}$ beyond the corolla throat in longistylous flowers. Anthers ellipsoid, $0.5-1 \mathrm{~mm}$ long, purple or white; filaments dorsifixed, $1.3-2 \mathrm{~mm}$ long in brevistylous flowers, $0.4-0.5 \mathrm{~mm}$ long in longistylous flowers. Pollen tricolporate, oblate spheroidal, prolate spheroidal or subprolate in brevistylous flowers, prolate spheroidal to subprolate in longistylous flowers; E $16-22 \mu \mathrm{m}$ in brevistylous flowers, $17-20 \mu \mathrm{m}$ in longistylous flowers; P 18-26 $\mu \mathrm{m}$ in brevistylous flowers, 21-22 $\mu \mathrm{m}$ in longistylous flowers; ectocolpi long; endocolpi long; tectum bireticulate; suprareticulum microreticulate to reticulate, smooth; infrareticulum perforate to microreticulate with granules and/or spines on the muri in brevistylous flowers, reduced in longistylous flowers to granules and/or spines in the lumina around the edges of the muri. Ovary 2-locular, broadly obovoid to broadly depressed obovoid, $0.5-0.7 \times 0.6-1.1 \mathrm{~mm}$, glabrous; placenta attached near the middle of the septum, stalked, subglobose, bearing few ovules per locule (but more than 3). Style 1-1.5 mm long and included in brevistylous flowers, 3-6 $\mathrm{mm}$ long and exserted for $2.4-5 \mathrm{~mm}$ beyond the corolla throat in longistylous flowers, papillate; stigma bilobed, lobes $0.7-0.9 \mathrm{~mm}$ long in brevistylous flowers, 


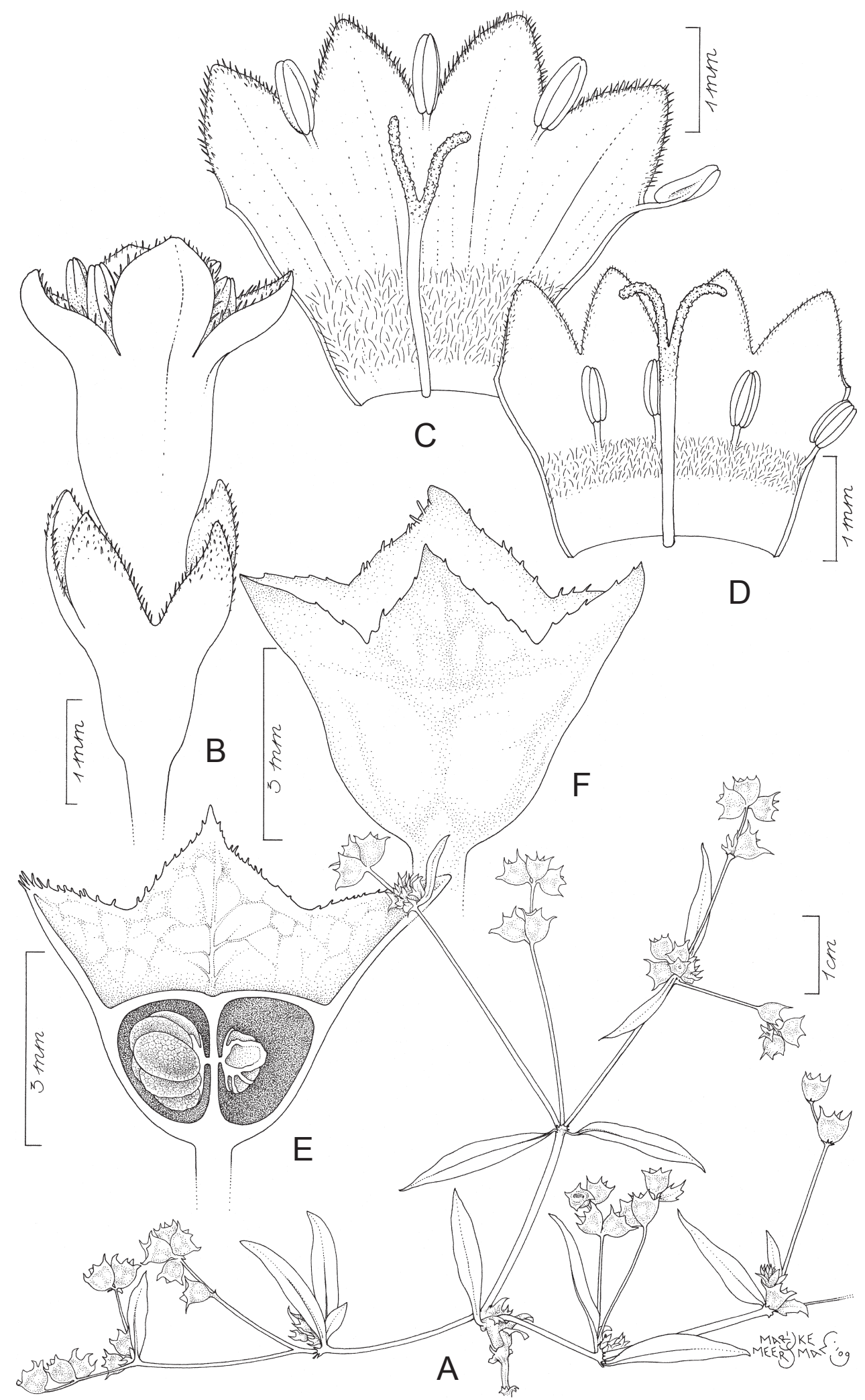

Fig. 15. Astiella pulla Groeninckx sp. nov. A. Habit. B. Brevistylous flower. C. Open brevistylous flower. D. Open longistylous flower. E. Ovary dissected to show placentation; all ovules removed from the right locule to show the placenta. F. Capsule. Drawn by Marijke Meersman. A, E-F from Perrier de la Bâthie 17633 (P); B-D from Groeninckx, De Block \& Rakotonasolo 271 (BR). 
0.7-2.3 mm long in longistylous flowers, hirtellous. Capsules broadly obovoid, $1.3-2.7 \mathrm{~mm}$ long, $2-$ $2.8 \mathrm{~mm}$ wide, crowned with the persistent calyx lobes, glabrous, green, dehiscence loculicidal. Seeds few per locule, elliptic in outline, ventral groove absent, $0.6-0.7 \times$ ca $0.5 \times$ ca $0.5 \mathrm{~mm}$, black or dark brown; seed coat surface reticulate, testa cells with undulating radial walls, microsculpturing granulate.

\section{Distribution}

E Madagascar: Antananarivo province, Analamanga region, Anjozorobe district; Antsiranana province, Melaky region, Besalampy district; Fianarantsoa province, Atsimo-Atsinanana region, Befotaka district; Fianarantsoa province, Horombe region, Ivohibe district; Mahajanga province, Sofia region, Bealanana district; Toamasina province, Alaotra-Mangoro region, Moramanga district; Toamasina province, Analanjirofo region, Maroantsetra district.

\section{Habitat}

Humid forest; along forest trails; secondary savannas; laterite substrate; at 0-1900 m elevation.

\section{Conservation status}

The species is known from 15 collections, of which two without locality. The number of locations is eight. The extent of occurrence is more than $20,000 \mathrm{~km}^{2}$; the area of occupancy equals $36 \mathrm{~km}^{2}$. Throughout the species' distribution range, there is a high human pressure on the natural habitats. The species is therefore classified as vulnerable: VU B2ab(i,ii,iii).

\section{Remarks}

The specimen Lantz s.n. could be included in A. perrieri sp. nov. although it has flowers with welldeveloped corolla tubes (2.3-2.6 mm long). Several other specimens collected on the Island of Nosy Mangabe (Carlson 179, Cheek 1380, Schatz \& Miller 2514, Schatz \& Villiers 1833) could be included as well, but these can be distinguished from the other A. perrieri specimens by their glabrous leaves. Because of these discrepancies, these specimens were not included in the species description.

Astiella pulla Groeninckx sp. nov. http://www.ipni.org/urn:1sid:ipni.org:names:77161727-1

Figs $2 \mathrm{~K}, 15$

\section{Diagnosis}

Astiella pulla sp. nov. resembles A. antsalovansis sp. nov. in having black seeds with a reticulate seed coat surface consisting of 5- to 6-angular testa cells and in having a ring of trichomes inside the corolla tube, but differs in having more robust inflorescence axes (vs slender), 4 to 5 ovules per locule (vs 3), a longer style that is always exserted in brevistylous flowers (vs a shorter style that is included), and fruits $1.5-3.4 \times 2.6-4 \mathrm{~mm}(\mathrm{vs} 1-2 \times 1.5-3 \mathrm{~mm})$.

\section{Etymology}

The specific epithet is the feminine form of the Latin adjective 'pullus' that means 'dark-coloured' and refers to the black seeds.

\section{Type}

MADAGASCAR: Mahajanga province, Boeny region, Mahajanga I district: ca $20 \mathrm{~km}$ before Mahajanga, Marohogo, RN 4, just next to road, 47 m, 19 Mar. 2010, Groeninckx, De Block \& Rakotonasolo 271 (holo-: BR; iso-: BR, G, K, MO, P, TAN, WAG). 


\section{Additional material examined}

MADAGASCAR: Mahajanga province, Boeny region, Mahajanga I district, sur le calc rocin à Marohogo près Majunga, s.d., Perrier de la Bâthie 17633 (P).

\section{Description}

Annual herb, erect, up to $20 \mathrm{~cm}$ tall; stems quadrangular in cross section, glabrous or sometimes scabrate on the ribs. Stipule base $0.2-1 \mathrm{~mm}$ long, beset with a few short trichomes; fimbriae $4-9,0.2-0.8 \mathrm{~mm}$ long, sometimes inconspicuous, colleter-tipped. Leaves sessile; blades ovate, elliptic, narrowly ovate or narrowly elliptic, $8-32 \times 3-8.5 \mathrm{~mm}$, glabrous, darker green above, paler green below; base attenuate; apex acute; margin revolute when dry, scabrate; midvein prominent below, glabrous or scabrate; secondary veins invisible or 3-4 on each side of the midvein; intersecondaries invisible. Inflorescences terminal or pseudo-axillary, very lax compound and reduced dichasia, 3- to several-flowered; bracts at main branchings leaf-like; peduncle absent; inflorescence branches up to $6 \mathrm{~cm}$ long, glabrous or scabrate. Pedicels absent or $0.5-1.5 \mathrm{~mm}$ long, glabrous or scabrate. Flowers heterostylous. Calyx green; tube reduced; lobes 4 , ovate with acuminate tip, $1-1.7 \times 0.7-1 \mathrm{~mm}$, glabrous, margin ciliolate. Corolla white; tube cylindrical $2.2-2.8 \times 1-1.5 \mathrm{~mm}$ in brevistylous flowers, $1.5-2.2 \times 0.8-1.2 \mathrm{~mm}$ in longistylous flowers, glabrous outside, with a ring of trichomes in the lower half inside; lobes 4, ovate, $0.6-1.4 \times$ $0.5-1.3 \mathrm{~mm}$, glabrous inside except for trichomes towards the margin. Stamens inserted near the base of the corolla lobes and exserted for $0.6-0.9 \mathrm{~mm}$ beyond the corolla throat in brevistylous flowers, inserted in the middle of the corolla tube and included in longistylous flowers. Anthers ellipsoid, $0.5-0.7 \mathrm{~mm}$ long; filaments dorsifixed, $0.4-0.5 \mathrm{~mm}$ long. Pollen 7-aperturate. Ovary 2-locular, depressed obovoid, $0.5-1 \times 0.7-1.3 \mathrm{~mm}$, glabrous to sparsely pubescent; placenta attached near the middle of the septum, stalked, subglobose, bearing 4 to 5 ovules per locule. Style $2.3-3 \mathrm{~mm}$ long and exserted for $0.2-0.3 \mathrm{~mm}$ beyond the corolla throat in brevistylous flowers, $2.5-2.8 \mathrm{~mm}$ long and exserted for $0.6-0.7 \mathrm{~mm}$ beyond the corolla throat in longistylous flowers, glabrous; stigma bilobed, lobes $0.5-0.8 \mathrm{~mm}$ long, hirtellous. Capsules broadly depressed obovoid, $1.5-3.4 \times 2.6-4 \mathrm{~mm}$, crowned with the persistent calyx lobes, glabrous or with a few scabrate trichomes, dehiscence loculicidal. Seeds 1,3 or 4 per locule, elliptic in outline, ventral groove absent, $0.8-1 \times 0.6-0.8 \times 0.4-0.5 \mathrm{~mm}$, hilum in the middle, black; seed coat surface reticulate, 5 - to 6 -angular testa cells, microsculpturing favulariate.

\section{Distribution}

NW Madagascar: Mahajanga province, Boeny region, Mahajanga I district.

\section{Habitat}

Western (degraded) dry forest; dark clay on calcareous underground; at $47 \mathrm{~m}$ elevation.

\section{Conservation status}

Known from only one locality. Given its apparent rarity and following the recommendation of Callmander et al. (2005) to avoid the Data Deficient category, we consider the species as vulnerable (VU D2) based on its restricted area of occupancy (D2) and the high human pressure present in the entire area resulting in a general decline of suitable habitats (dry forest) for the species.

Astiella tsaratanensis Groeninckx sp. nov. http://www.ipni.org/urn:1sid:ipni.org:names:77161729-1

Figs $2 \mathrm{~L}, 5 \mathrm{P}-\mathrm{R}, 11 \mathrm{D}, 16$

\section{Diagnosis}

Astiella tsaratanensis sp. nov. resembles A. delicatula Jovet in having a reduced number of ovules per locule, pluricolporate pollen, and seeds with a ventral groove, but differs in having 3 ovules per locule (vs 1 ), and 4 calyx lobes (vs 2). 


\section{Etymology}

The species epithet refers to the Madagascan town Tsaratanana.

\section{Type}

MADAGASCAR: Antsiranana province, Diana region, Antsiranana I district, Montagne d'Ambre NP, circuit Gite d'Etape-Cascade Antakarana-Voie des Milles Arbres-Gite d'Etape, 20 Jan. 2002, De Block, Rakotonasolo \& Randriamboavonjy 1319 (holo-: BR; iso-: BR, CAS, G, K, MO, P, TAN, WAG).

\section{Additional material examined}

MADAGASCAR: Antananarivo province, Analamanga region, Ankazobe district, Ambatoharanana près d'Antsevabe, 1000 m, 6 Mar. 1951, Cours 4079 (P). Vakinankaratra region, Ambatolampy district, Province du Vakinankaratra, district d'Ambatolampy, à 3-4 km en aval de Tsinjoarivo, dans la vallée de l'Onive, bords d'un ruisseau dans la forêt, 1550 m, 30 Nov. 1912, Viguier \& Humbert 1846 (P). Antsiranana province, Diana region, Ambanja district, Montagne Tsaratanana, sousbois, $1000 \mathrm{~m}$, Dec. 1912, Perrier de la Bâthie 3730 (P). Antsiranana I district, Centre nord, Montagne d'Ambre, bords du bois, basalte, 1000 m, Nov. 1909, Perrier de la Bâthie 9403 (P); Southwest of Antsiranana, Joffreville, Parc National de Montagne d'Ambre, 990-1100 m, 16-20 Nov. 1992, Malcomber et al. 1749 (K, P, TAN); Environs de Diego-Suarez, forêt d'Ambre, forêt ombrophile sur argile latéritique de basalte, $1000 \mathrm{~m}$, 23 Dec.-18 Jan. 1960, Humbert 32085 (BR, P). Fianarantsoa province, Atsimo-Atsinanana region, Farafangana district, RN 3, Manaka Est, [Atondrazaka], bas-fond, 5 Nov. 1952, Botoalina 4475-RN (P). Mahajanga province, Sofia region, Bealanana district, Montagnes au nord de Mangindrano (haute Maevarano), jusqu' aux sommets d'Ambohimirahavavy (partage des eaux Mahavavy-Androranga: centrenord), forêt ombrophile sur latérite de gneiss, clairières marécageuses aux origines de la Bemafo affluent de l'Androranga, 1900 m, 19 Jan.-12 Feb. 1951, Humbert \& Capuron 24975 (BR, P); Montagnes au nord de Mangindrano (haute Maevarano), jusqu'aux sommets d'Ambohimirahavavy (partage des eaux Mahavavy-Androranga: centre-nord), clairières en forêt ombrophile sur latérite de gneiss, aux bords de la Bemafo, affluent de l'Androranga, 1800 m, 19 Jan.-12 Feb. 1951, Humbert \& Capuron 25077 (P). Toamasina province, Alaotra-Mangoro region, Ambatondrazaka district, Ambatondrazaka, endroits très humides, station 0-114, $800 \mathrm{~m}$, Nov. 1938, Cours s.n. (BR, P); Ouest, massif de l'Andringitra prês d'Ambodipaiso, près d'Antsoabe, Manaka Est, ca 1200 m, 12 Jan. 1945, Cours 2316 (BR, MO, P). Locality unknown, s. loc., s.d., Baron 6312 (P); s. loc., s.d., Homolle s.n. (P).

\section{Description}

Herb, scrambling or prostrate, up to $30 \mathrm{~cm}$ tall, with fine rooting system, rooting at the nodes; stems round in cross section, only sparsely branching, glabrous to sparsely pubescent, pale green to reddish green, tinged red near the nodes. Stipule base 1.3-1.5 mm long, sparsely to densely beset with trichomes (ca $0.6 \mathrm{~mm}$ long); fimbriae 1-6, variable in length up to $2.5 \mathrm{~mm}$ long, colleter-tipped. Leaves petiolate; petioles $1.5-17 \mathrm{~mm}$ long, glabrous; blades ovate or elliptic, rarely broadly elliptic, 5.5-39 $\times 3.5-20.3 \mathrm{~mm}$, sparsely to moderately covered with appressed trichomes $0.1-1.5 \mathrm{~mm}$ long, mostly concentrated on midvein and secondary veins, darker green above, paler green below; base attenuate; apex acute; margin scabrate or ciliate; midvein prominent below; secondary veins $3-5$ on each side of the midvein, prominent particularly below; intersecondaries invisible. Inflorescences pseudo-axillary, 1- or fewflowered dichasia; peduncle 11-27 mm long, glabrous. Pedicels 1-7.7 mm long, glabrous, green tinged reddish. Flowers heterostylous. Calyx green; tube reduced; lobes 4, narrowly triangular to linear, 1-2 $\times 0.2-0.5 \mathrm{~mm}$, glabrous or sparsely beset with trichomes, margin usually scabrate rarely beset with long trichomes, colleters in between. Corolla white or pale blue; tube funnel-shaped, $4.8-9.5 \mathrm{~mm}$ long, $0.5-1 \mathrm{~mm}$ wide at the base, $2-4.2 \mathrm{~mm}$ wide at the throat, glabrous outside, sparsely to moderately beset with trichomes inside; lobes 4, ovate, 3.4-5 × 1.1-2.5 mm, glabrous outside, moderately beset with trichomes inside. Stamens inserted in the corolla throat and exserted for ca $1 \mathrm{~mm}$ beyond the 


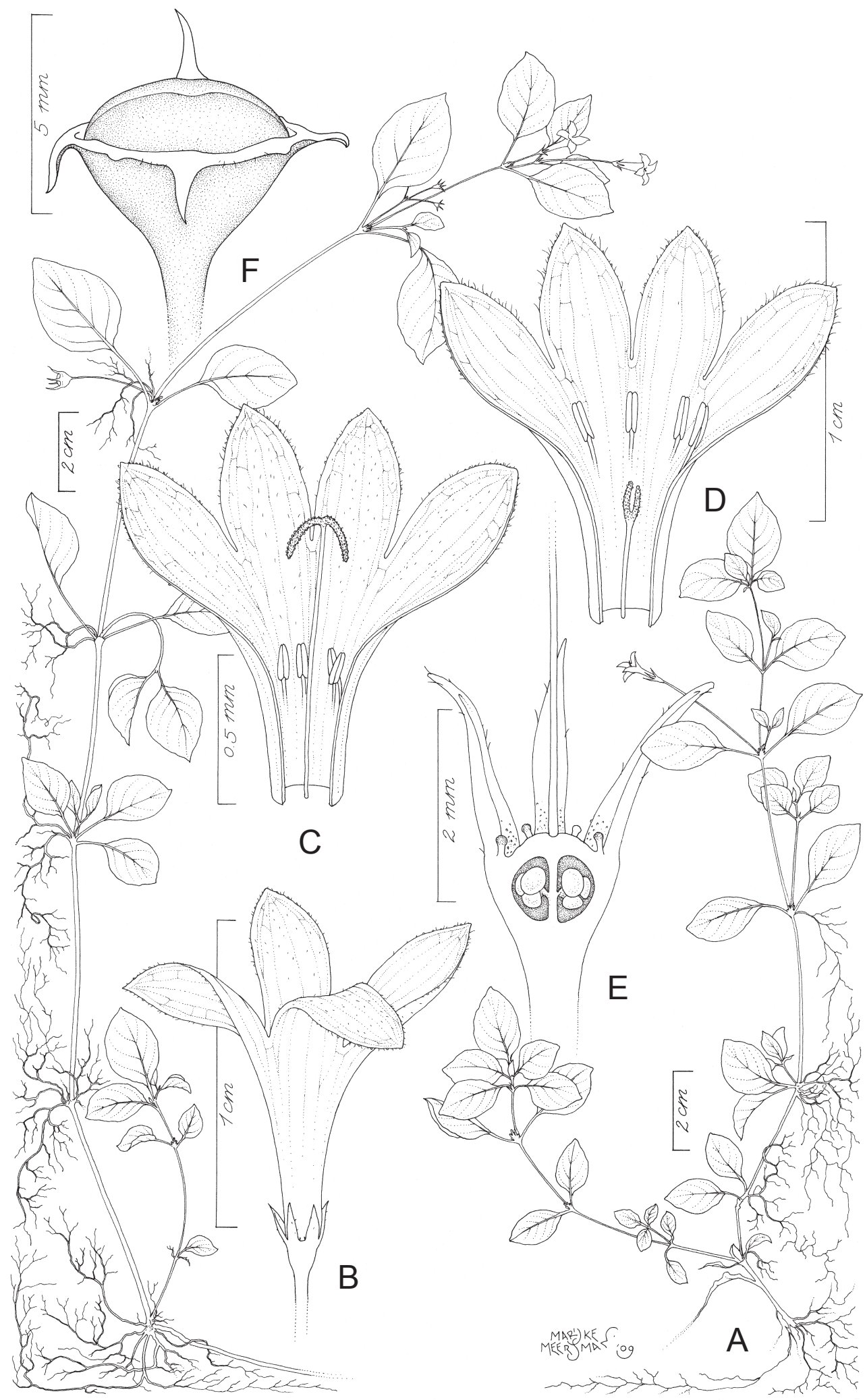

Fig. 16. Astiella tsaratanensis Groeninckx sp. nov. A. Habit. B. Brevistylous flower. C. Open longistylous flower. D. Open brevistylous flower. E. Ovary dissected to show placentation. F. Capsule. Drawn by Marijke Meersman. A-C, E-F from De Block, Rakotonasolo \& Randriamboavonjy 1319 (BR); D from Humbert \& Capuron 24975 (BR). 
corolla throat or included in brevistylous flowers, inserted in the lower half of the corolla tube and included in longistylous flowers. Anthers ellipsoid, $0.8-1 \mathrm{~mm}$ long; filaments dorsifixed, $0.3-0.8 \mathrm{~mm}$ long. Pollen 7- to 8-colporate, suboblate; E 34-37 $\mu \mathrm{m}$; P 26-29.5 $\mu \mathrm{m}$; ectocolpi short; endocolpi short; tectum bireticulate; suprareticulum microreticulate to reticulate, smooth; infrareticulum perforate to microreticulate with granules. Ovary 2-locular, broadly obovoid to broadly depressed obovoid, $0.4-1$ $\times 0.6-0.9 \mathrm{~mm}$, glabrous; placenta attached near the middle of the septum, stalked, globose, bearing 3 ovules per locule. Style 3.6-4 mm long and included in brevistylous flowers, 9-11 mm long and exserted for $1.2-2 \mathrm{~mm}$ beyond the corolla throat or included in longistylous flowers, glabrous; stigma bilobed, lobes $0.6-1.2 \mathrm{~mm}$ long in longistylous flowers, $0.5-0.9 \mathrm{~mm}$ in brevistylous flowers, papillate, pale blue. Capsules broadly depressed obovoid, $2.5-4.6 \times 3.2-5 \mathrm{~mm}$, crowned with the persistent calyx lobes, glabrous, green, dehiscence loculicidal. Seeds 1 per locule, elliptic in outline, ventral groove present, $1.9-2.3 \times 1.4-1.5 \mathrm{~mm}$, black; seed coat surface alveolate, microsculpturing rugulose.

\section{Distribution}

NW to E Madagascar: Antananarivo province, Analamanga region, Ankazobe district; Antananarivo province, Vakinankaratra region, Ambatolampy district; Antsiranana, province, Diana region, Ambanja, and Antsiranana I districts; Fianarantsoa province, Atsimo-Atsinanana region, Farafangana district; Mahajanga province, Sofia region, Bealanana district; Toamasina province, Alaotra-Mangoro region, Ambatondrazaka district.

\section{Habitat}

Humid forest; along forest stream, forest border; basalt-laterite; at 800-1900 m elevation.

\section{Conservation status}

The species is known from 14 collections, of which two without locality. The number of locations is nine. The extent of occurrence is more than $20,000 \mathrm{~km}^{2}$; the area of occupancy equals $40 \mathrm{~km}^{2}$. The main threat for the species is the deterioration of its habitat caused by the high human pressure throughout its distribution range, which has also been observed within the protected areas. A decline in the extent of occurrence, area of occupancy, and area, extent, and/or quality of habitat is projected. The species is therefore classified as vulnerable: VU B2ab(i,ii,iii).

\section{Discussion}

\section{The expanded genus Astiella}

Astiella is no longer monospecific but includes, besides $A$. delicatula, also A. antongilensis sp. nov., A. antsalovansis sp. nov., A. confusa sp. nov., A. deblockiae sp. nov., A. desseinii sp. nov., A. homolleae sp. nov., A. latifolia sp. nov., A. longifimbria sp. nov., A. perrieri sp. nov., A. pulla sp. nov., and A. tsaratanensis sp. nov. The genus now holds 12 species that are all endemic to Madagascar. Most species have a limited distribution range but a few occur throughout the island (Fig. 2). Several Astiella species were included in a recent molecular phylogenetic analysis and they were shown to be monophyletic and part of the Spermacoceae s. lat. tribe in Rubiaceae (Janssens et al. 2016). Morphologically, the newly described species also fit the Spermacoceae s. lat. tribe: they are rather small annual or perennial herbs with raphides, fimbriate stipules, tetramerous heterostylous white flowers, two-lobed styles, bilocular ovaries, and multi-ovulate placentas attached to the middle of the septum. The phylogenetic study furthermore demonstrated that the newly described species are part of the TAPA clade, a clade consisting of the Madagascan genera Thamnoldenlandia, Amphistemon, Phialiphora, and Astiella (Janssens et al. 2016). Although a single morphological synapomorphy could not be identified for the different Astiella species, there is little doubt that the 11 newly described species are part of the genus Astiella. Firstly, A. delicatula was also included in the phylogenetic analysis and the newly described species clearly form 
a monophyletic group around the type species, significantly separated from the other closely related genera (Janssens et al. 2016). Secondly, all newly described species are morphologically quite different from the three closest related genera: the two Phialiphora species have basal leaves that form \pm a rosette, typical involucrate head-like inflorescences, isostylous flowers with exserted stamens, and heart-shaped placentas distally attached to the septum (Groeninckx et al. 2010a); the two Amphistemon species are perennial herbs or much-branched subshrubs with well-developed taproots and their stamens are inserted at two levels in the corolla tube (Groeninckx et al. 2010b); and Thamnoldenlandia ambovombensis Groeninckx is a $1.5 \mathrm{~m}$ tall woody shrub with linear leaves and winged seeds (Groeninckx et al. 2010b). None of the newly described species possess any of these characters. The combination of molecular and morphological evidence clearly places the species together in an expanded genus Astiella.

\section{Species groups within Astiella}

Although the genus seems to be morphologically variable (e.g. the variation in the number of ovules), several distinct groups can be recognized within Astiella based on character combinations that define two or more species and by combining the morphological data with the molecular evidence from Janssens et al. (2016).

A first group includes A. delicatula, A. tsaratanensis sp. nov., and A. confusa sp. nov. The first two species are similar in having ovaries with a reduced number of ovules per locule (respectively one and three ovules per locule of which only one develops into a seed; Figs 8D, 16E), pluricolporate pollen (Figs 4C, 11D), and seeds with a ventral groove (Fig. 5H, Q). This character combination is very rare within the Hedyotis-Oldenlandia complex in which species generally have multi-ovulate locules, tricolporate pollen and seeds without a ventral groove (Groeninckx et al. 2009). Moreover, the two species have relatively large leaves, terminal inflorescences, flowers with a well-developed corolla tube, and broadly depressed obovoid capsules (Figs 8, 16). Their close relationship has also been confirmed by a molecular phylogenetic study (Janssens et al. 2016). Astiella confusa sp. nov. resembles A. delicatula and $A$. tsaratanensis sp. nov. in having a reduced number of ovules per locule (viz. three ovules per locule; Fig. 6D) and in having seeds with a ventral groove, a character that is lacking in other Astiella species.

A second group includes $A$. antsalovansis sp. nov. and A. pulla sp. nov. The two species resemble the first group in having a reduced number of ovules per locule (Figs 3E, 15E) and pluri-aperturate pollen (Fig. 4A). However, they differ from the first group by having seeds without a ventral groove (Fig. 5A). Their seeds also have a reticulate seed coat surface consisting of 5- to 6-angular testa cells with verruculate or favulariate microsculpturing (Fig. 5B). As seed and pollen characters have proven to be useful to delimit species and genera within Spermacoceae s. lat. (e.g. Dessein et al. 2003; Groeninckx et al. 2010b), it is appropriate to consider A. antsalovansis sp. nov. and A. pulla sp. nov. as sister species and most probably closely related to group one.

A third group includes $A$. antongilensis sp. nov., A. deblockiae sp. nov., A. desseinii sp. nov., A. homolleae sp. nov., A. latifolia sp. nov., and $A$. perrieri sp. nov. The species of this group are characterized by several ovules per locule (Figs 1D, 7E, 9F, 10E, 12E, 14E), tricolporate pollen (Figs 4B, D, 11A-C), and seeds without a ventral groove (Fig. 5C, E, J, L, N). Except for A. antongilensis sp. nov., all species of this third group are also characterized by having pollen with a bireticulate tectum (Figs 4B, D, 11AC). The molecular phylogenetic study supports the close relationship of these species and they form a monophyletic group (Janssens et al. 2016). Astiella desseinii sp. nov. and A. latifolia sp. nov. are morphologically more similar, as both have sessile flowers (Figs 9A, 12A), elongated placentas (Figs 9F, 12E), and ovoid capsules (Figs 9E, 12F). The latter two characters are exceptional in Astiella, where globose placentas and broadly depressed obovoid capsules are more common. Their pollen and seed morphology are also very similar: pollen is tricolporate with a microreticulate to reticulate suprareticulum 
and a well-developed perforate to microreticulate infrareticulum with granules on the muri (Figs 4D, 11B), and the seeds are elliptic in outline, have a reticulate seed coat surface, testa cells with undulating radial walls and granulate microsculpturing (Fig. 5E-F, L-M). The other four species in the group, A. antongilensis sp. nov., A. deblockiae sp. nov., A. homolleae sp. nov., and A. perrieri sp. nov., are characterized by a reduced corolla tube with the stamens always exserted beyond the corolla throat (Figs 1B, 7B, 10B, 14B). The largest reduction is found in A. antongilensis sp. nov. and A. homolleae sp. nov.: their corolla tube is maximum $0.6 \mathrm{~mm}$ long. In $A$. deblockiae sp. nov., longistylous flowers have more reduced corolla tubes than brevistylous flowers $(0.8-1 \mathrm{~mm}$ vs $1.5-2.2 \mathrm{~mm})$. In A. perrieri sp. nov., corolla tubes can be up to $1.5 \mathrm{~mm}$ long.

The last species included in Astiella is A. longifimbria sp. nov.. It is morphologically similar to the species of group three because of the numerous ovules per locule (Fig. 13D). Also, it is characterized by long fimbriate stipules (Fig. 13A), a character observed in A. homolleae sp. nov. as well (Fig. 10A). Astiella longifimbria sp. nov., however, differs in having a well-developed corolla tube (Fig. 13B).

\section{Acknowledgements}

We thank Marijke Meersman for the beautiful line drawings. Research in Madagascar was facilitated by the following Madagascan governmental institutions, which provided permission to collect specimens in protected areas: Madagascar National Parks (formerly known as Association Nationale pour la Gestion des Aires Protégées (ANGAP)), Ministère des Eaux et Forêts (MEF) and Parc Botanique et Zoologique de Tsimbazaza (PBZT). We thank Dr. P. Lowry, Head of the Africa and Madagascar Department of Missouri Botanical Garden, for the opportunity to perform fieldwork within the framework of MBG's Madagascar Research and Conservation Program. We also thank the members of the MBG staff in Madagascar for their hospitality and help. We are grateful to Dr. Franck Rakotonasolo (PBZT), Dr. Steven Dessein (BR), Dr. Petra De Block (BR), and Dr. James Tosh, who accompanied the first author in the field. This research was supported by grants from the Research Foundation - Flanders (FWO, G.0205.05 and G.0268.04).

\section{References}

Anonymous 1962. Systematics association committee for descriptive biological terminology. II. Terminology of simple symmetrical plane shapes (chart 1). Taxon 11: 145-156. http://dx.doi. org/10.2307/1216718

Bachman S., Moat J., Hill A.W., De la Torre J. \& Scott B. 2011. Supporting Red List threat assessments with GeoCAT: geospatial conservation assessment tool. In: Smith V. \& Penev L. (eds) e-Infrastructures for data publishing in biodiversity science. ZooKeys 150: 117-126. https://doi.org/10.3897/ zookeys.150.2109

Beentje H. 2012. The Kew Plant Glossary, an illustrated dictionary of plant terms. Revised edition. Royal Botanic Gardens, Kew.

Callmander M.W., Schatz G.E. \& Lowry P.P. 2005. IUCN Red List assessment and the global strategy for plant conservation: taxonomists must act now. Taxon 54: 1047-1050.

Dessein S., Ntore S., Robbrecht E. \& Smets E. 2003. Pollen and seeds reveal that Spermacoce thymoidea s.l. (African Rubiaceae, Spermacoceae) represents three endemic or disjunct species from the Zambesian high plateaus. Systematic Botany 28: 130-144. http://www.jstor.org/stable/3093943

Govaerts R., Ruhsam M., Andersson L., Robbrecht E., Bridson D., Davis A., Schanzer I. \& Sonké B. 2016. World Checklist of Rubiaceae. The Board of Trustees of the Royal Botanic Gardens, Kew. Available from http://apps.kew.org/wcsp [accessed 29 Jul. 2016]. 
Groeninckx I., Dessein S., Ochoterena H., Persson C., Motley T.J., Karehed J., Bremer B., Huysmans S. \& Smets E. 2009. Phylogeny of the herbaceous tribe Spermacoceae (Rubiaceae) based on plastid DNA data. Annals of the Missouri Botanical Garden 96: 109-132. http://dx.doi.org/10.3417/2006201

Groeninckx I., Briggs M., Davis A., De Block P., Robbrecht E., Smets E. \& Dessein S. 2010a. A new herbaceous genus endemic to Madagascar: Phialiphora (Spermacoceae, Rubiaceae). Taxon 59: 18151829.

Groeninckx I., De Block P., Robbrecht E., Smets E. \& Dessein S. 2010b. Amphistemon and Thamnoldenlandia, two new genera of Rubiaceae (Spermacoceae) endemic to Madagascar. Botanical Journal of the Linnean Society 163: 447-472. http://dx.doi.org/10.1111/j.1095-8339.2010.01060.x

IUCN 2001. IUCN Red List Categories: Version 3.1. IUCN Species Survival Commission, Cambridge. Available from http://www.iucnredlist.org/technical-documents/categories-and-criteria/2001categories-criteria [accessed 24 Jan. 2017].

Janssens S., Groeninckx I., De Block P., Verstraete B., Smets E. \& Dessein S. 2016. Dispersing towards Madagascar: biogeography and evolution of the Madagascan endemics of the Spermacoceae tribe (Rubiaceae). Molecular Phylogenetics and Evolution 95: 58-66. http://dx.doi.org/10.1016/j. ympev.2015.10.024

Jovet P. 1941. Astiella delicatula, espèce nouvelle d'un genre nouveau malgache (RubiacéesOldenlandiées). Notulae Systematicae 9: 146-156.

Moat J. \& Smith P. 2007. Atlas of the vegetation of Madagascar. Royal Botanic Gardens, Kew.

Punt W., Hoen P.P., Blackmore S., Nilsson S. \& Le Thomas A. 2007. Glossary of pollen and spore terminology. Review of Palaeobotany and Palynology 143: 1-81. http://dx.doi.org/10.1016/j. revpalbo.2006.06.008

Reitsma T. 1969. Size modifications of recent pollen grains under different treatments. Review of Palaeobotany and Palynology 9: 175-202. http://dx.doi.org/10.1016/0034-6667(69)90003-7

Schols P., Dessein S. \& Smets E. 2001. iMap version 2.0. Available from www.biovolution.com

Schols P., Dessein S., D’hondt C., Huysmans S. \& Smets E. 2002. Carnoy: a new digital measurement tool for palynology. Grana 41: 124-126. http://dx.doi.org/10.1080/001731302760156936

Thiers B. Continuously updated. Index Herbariorum, a global directory of public herbaria and associated staff. Available from http://sweetgum.nybg.org/ih/ [accessed 24 Jan. 2017].

Manuscript received: 9 February 2016

Manuscript accepted: 1 August 2016

Published on: 25 April 2017

Topic editor: Koen Martens

Desk editor: Connie Baak

Printed versions of all papers are also deposited in the libraries of the institutes that are members of the EJT consortium: Muséum national d'Histoire naturelle, Paris, France; Botanic Garden Meise, Belgium; Royal Museum for Central Africa, Tervuren, Belgium; Natural History Museum, London, United Kingdom; Royal Belgian Institute of Natural Sciences, Brussels, Belgium; Natural History Museum of Denmark, Copenhagen, Denmark; Naturalis Biodiversity Center, Leiden, the Netherlands. 